\title{
CALIXARENE METHYLENE BISPHOSPHONIC ACIDS AS PROMISING EFFECTORS OF BIOCHEMICAL PROCESSES
}

\author{
S. V. KOMISARENKO', S. O. KOSTERIN ${ }^{1}$, E. V. LUGOVSKOY', V. I. KALCHENKO' \\ ${ }^{1}$ Palladin Institute of Biochemistry, National Academy of Sciences of Ukraine, Kyiv; \\ e-mail: kinet@biochem.kiev.ua; \\ ${ }^{2}$ Institute of Organic Chemistry, National Academy of Sciences of Ukraine, Kyiv; \\ e-mail:vik@ioch.kiev.ua
}

\begin{abstract}
This interdisciplinary study, performed with participation of research workers of Palladin Institute of Biochemistry and Institute of Organic Chemistry of NAS of Ukraine, is devoted to analysis of biochemical effects of some calixarene methylene bisphosphonic acids (cyclic phenol oligomers) on two well-known biological phenomenons - $\mathrm{Mg}^{2+}$-dependent ATP hydrolysis (myosin subfragment-1 of myometrium smooth muscle was used as an example) and fibrin polymerization.

Calix[4]arene C-97 (calix[4]arene methylene bisphosphonic acids) is a macrocyclic substance, which contains intramolecular highly ordered lipophilic cavity formed by four aromatic rings, one of which is functionalized at the upper rim with methylene bisphosphonic group. At concentration of $100 \mu \mathrm{M}$, this substance was shown to effectively inhibit ATPase activity of pig myometrium myosin subfragment-1 (inhibition coefficient $\left.I_{0.5}=83 \pm 7 \mu \mathrm{M}\right)$. At the same time, this calix[4]arene causes significant (vs. control) increase of myosin subfragment-1 hydrodynamic diameter, which may indicate formation of an intermolecular complex between calixarene and myosin head. Computer simulation methods (docking and molecular dynamics with addition of grid technologies) enabled to elucidate the grounds of intermolecular interactions between calix[4]arene C-97 and myometrium myosin subfragment-1, that involve hydrophobic, electrostatic and $\pi$ - $\pi$-stacking interactions, some of which are close to the ATPase active centre. In view of the ability of calixarenes to penetrate into the cell and their low toxicity, the results obtained may be used as a basis for further development of a new generation of supramolecular effectors (starting from the above mentioned substances, in particular calix[4]arene C-97) for regulation of smooth muscle contractile activity at the level of ATP dependent actin-myosin interaction.

Calix[4]arenes bearing two or four methylenebisphosphonic acid groups at the macrocyclic upper rim have been studied with respect to their effects on fibrin polymerization. The most potent inhibitor proved to be calix [4]arene tetrakis-methylene-bis-phosphonic acid (C-192), in which case the maximum rate of fibrin polymerization in the fibrinogen + thrombin reaction decreased by $50 \%$ at concentrations of $0.52 \cdot 10^{-6} M\left(I C_{50}\right)$. At this concentration, the molar ratio of the compound to fibrinogen was 1.7:1. For the case of desAB fibrin polymerization, the $I C_{50}$ was $1.26 \cdot 10^{-6} \mathrm{M}$ at a molar ratio of $C-192$ to fibrin monomer of $4: 1$. Dipropoxycalix[4]-arene bis-methylene-bis-phosphonic acid (C-98) inhibited fibrin desAB polymerization with an $I C_{50}=1.31 \cdot 10^{-4} \mathrm{M}$. We hypothesized that $C-192$ blocks fibrin formation by combining with polymerization site ' $A$ ' (Aa17-19), which ordinarily initiates protofibril formation in a 'knob-hole' manner. This suggestion was confirmed by an HPLC assay, which showed a host-guest inclusion complex of C-192 with the synthetic peptide Gly-Pro-Arg-Pro, an analogue of site ' $A$ '. Further confirmation that the inhibitor was acting at the initial step of the reaction was obtained by electron microscopy, with no evidence of protofibril formation being evident. Calixarene C-192 also doubled both the prothrombin time and the activated partial thromboplastin time in normal human blood plasma at concentrations of $7.13 \cdot 10^{-5}$ and $1.10 \cdot 10^{-5} \mathrm{M}$, respectively. These experiments demonstrate that $C-192$ is a specific inhibitor of fibrin polymerization and blood coagulation and can be used for the design of a new class of antithrombotic agents.
\end{abstract}

Key words: methylene bisphosphonic acid, calixarenes, ATPase activity, docking, fibrin polymerization, fibronogen, fibrin, inhibition.

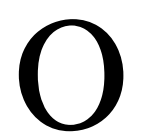
ne of most important methodological approaches, applied in molecular and cellular technologies in biochemistry, molecular biology and biophysics, that is focused on the study of structural and functional properties of biomolecules, supramolecular complexes and subcellular and membrane structures, is based on the use of natural and artificial effectors $E$ (activators and inhibitors) for modifying activities of enzymatic, transport, regulator and signaling proteins. Therefore, studying physico-chemical and biochemical basis and mechanisms involving interactions of 
small effector molecules with biomacromolecules and biomembranes has become currently one of the basic problems of so called "contact biology". It would be no exaggeration to say that "contact" events play a crucial role in realization of practically all fundamental biological phenomena that are studied by transdisciplinary sciences of chemico-biological direction.

It is obvious that an artificial effector $E$ pretending to form a "molecular platform" able to effectively regulate the functional activity of an intracellular protein must satisfy, as minimum, the following conditions: 1) to be nontoxic and nonimmunogenic for the organism; 2) to penetrate rather well through the plasmatic cellular membrane; 3 ) to function as a reversible mechanism; 4) to show a specific (selective) effect exactly on a specific protein; 5) to be characterized by a relatively high affinity towards a target protein (effector constant $K_{\mathrm{e}}<10^{-5} \mathrm{M}$ ).

In the context of the above mentioned, much attention of researches is currently devoted to phenol cyclic oligomers, calixarenes, as perspective artificial effectors for different biochemical processes.

Calixarenes [1] are vase shaped macrocyclic compounds produced synthetically by precise cyclo-condensation of $p$-substituted phenols and formaldehyde, which possess intramolecular lipophilic cavities formed by aromatic rings of the macrocyclic skeleton (Fig. 1). Calixarenes may be easily functionalized at the upper or lower rims of the macrocyclic skeleton.

Due to their ability to form a variety of interactions - multi-site hydrogen bonding, specific stacking, and generalized electrostatic interac- tions - calixarene derivatives can be applied as valid recognition motifs when developing synthetic supramolecular systems. They have the unique ability to recognize and bind to the Host-Guest supramolecular complexes, cations, anions and neutral molecules of appropriate size and architecture [2]. These properties open wide perspectives for practical application of calixarenes in different branches of chemistry, physics and biology [3, 4].

During the last 10 years, calixarene derivatives, especially water soluble and amphiphilic ones, have been the subject of growing interest in the field of biology. Highly diverse biomedical applications of these molecules now include antibacterial, anticancer, antiviral, antithrombotic, membranotropic activities, selective enzyme blocking and mimicking, as well as protein complexation [5]. Calixarenes, substituted at the upper or/ and lower macrocyclic rim with biologically active functional groups, are considered as promising compounds for treating many diseases [6].

We were interested in modifying the calixarene platform by bio-inspired methylene bisphosphonates. Being structural analogs of natural pyrophosphate, these compounds demonstrate versatile bioactivities [7, 8]. The bioactivities of bisphosphonates were investigated in detail by $\mathrm{S}$. Komisarenko in the Palladin Institute of Biochemistry, NAS of Ukraine. There were revealed and carefully examined antitumor and immunomodulating activities of methylene bisphosphonic acid (MBPHA) (Fig. 2) [9, 10].

Phosphonates and bisphosphonates are structural analogs of inorganic pyrophosphate $\left(\mathrm{PP}_{\mathrm{i}}\right)$ and phosphate, accordingly; they were chosen

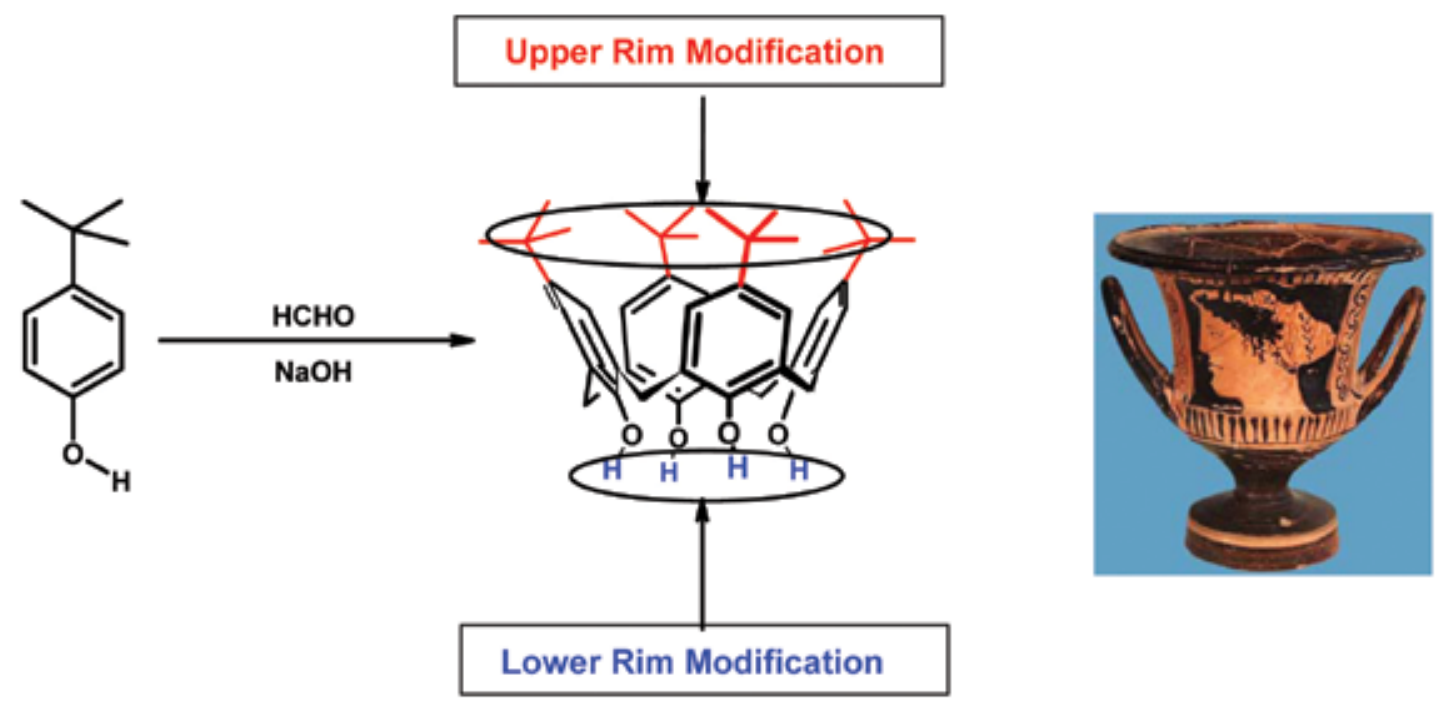

Fig. 1. Synthesis and structure of calix[4]arene 
for the study a priori in consideration of the fact that $\mathrm{PP}_{\mathrm{i}}$ takes part as a product or substrate in a large number of most important enzymatic reactions. It also may be found in many metabolites. The presence of $\mathrm{P}-\mathrm{C}$ bonds in phosphonates and $\mathrm{P}-\mathrm{C}-\mathrm{P}$ bonds in bisphosphonates, which usually cannot be hydrolyzed by enzymes, and strong complex forming abilities of phosphonates suggest that these substances may be used for perturbation of cell metabolic pathways; although, according to some literature data, bisphosphonates do not influence the activity of a large quantity of enzymes, in particular pyrophosphatase. Unlike this opinion, S. Komisarenko et al. showed that bisphosphonates were effective inhibitors of inorganic pyrophosphatase and some other enzymes in reactions involving inorganic pyrophosphate [11-16]. There was also shown antitumor effect of MBPHA - the property, which needed further analysis and preclinical investigations. In particular, there were investigated the mechanism of bisphosphonate effect and dependence of enzyme activities on the structure of bisphosphonates. MBPHA was shown to possess immunomodulatory activity. Thus, when introduced to animals, MBPHA caused inhibition of both biosynthesis of antibodies to T-dependent antigens and cell immune response reactions. It also inhibited biosynthesis of IgM-, IgE- and, especially, IgG-class antibodies but did not influence the composition of lymphocyte subpopulation. Other examined bisphosphonates (oxy- and aminoderivatives of MBPHA) were strong complex forming substances but did not possess immunomodulatory effect. MBPHA and its analogs oxyethylidene bisphosphonic acid, amino-MBPHA and phosphonoacetic acid - showed no toxicity and did not inhibit lymphocyte proliferation in culture when stimulated by mitogens. MBPHA did not essentially influence synthesis of specific interleukins by lymphocytes. It could not go through placental barrier and showed no embryo toxic effect. Use of ${ }^{14} \mathrm{C}$-MBPHA made it possible to reveal MBPHA tropism towards lymphoid cells and determine kinetic and thermodynamic parameters of MBPHA transport into cells. The data obtained suggest that MBPHA could penetrate into lymphocytes with a transporter through the concentration gradient by means of the facilitated diffusion mechanism. Such transport may be competitively inhibited by $\mathrm{PP}_{\mathrm{i}}$ and oxyethylidene bisphosphonic acid (but no $\mathrm{P}_{\mathrm{i}}$ ) and does not depend on the intensity of ATP synthesis in the cell. There were calculated and determined types of structural complexes that contain bisphosphonates inside cells and analyzed complexes with biologically important metals, which may interact with cell enzymatic systems [17].
Substances, which differed in a number of phosphoryl groups, type of bonds $(\mathrm{P}-\mathrm{C}, \mathrm{P}-\mathrm{O}$ or $\mathrm{P}-\mathrm{N}$ ) or charge and molecular size, were used to study the mechanism by which bisphosphonates and phosphonates may influence the activity of a number of key enzymes responsible for transformation of $\mathrm{PP}_{\mathrm{i}}$ or molecules including $\mathrm{PP}_{\mathrm{i}}$. $\mathrm{S}$. Komisarenko et al. came to the conclusion that tropism for lymphocytes is the basis of immunomodulatory effects of phosphonates (first of all, MBPHA). Transport and accumulation of MBPHA in lymphocytes results in inhibition of inorganic pyrophpsphatase activity and increase of local $\mathrm{PP}_{\mathrm{i}}$ concentration; later, different ligand complexes of bisphosphonates with bivalent metal ions and with $\mathrm{PP}_{\mathrm{i}}$ are formed and some enzymes change their activity, in particular, DNA-dependent RNA-polymerase II, enzymes of purine metabolism and so on [18].

On the basis of bisphosphonates, several prototypes of medicinal substances were developed [19-21]. Thus, a polyurethane composition was synthesized that might serve as an immobilized immunomodulator with local anti-inflammatory and immunosuppressive effects. It was shown that disodium salt of methylene bisphosphonic acid had antitumor properties, which resulted in development of a new antitumor preparation MEBIFON that was tested clinically and is currently produced in Kiev by the Public company FARMAK VAT. With the use of immunoglobulins (antibodies) and phosphoorganic complexons (aminobisphosphonates), there were synthesized immunovector molecules with antibody activities that conserved complex forming properties. Such structures were proposed, in particular, for radioimmunolocalisation of antigens. It should be noted that the above-mentioned investigations under the direction of S. Komisarenko were realized together with the following research workers of the Palladin Institute of Biochemistry, NAS of Ukraine: N. M. Gula, G. G. Gaivoronska, M. G. Juravsky, N. P. Karlova, I. M. Kolesnikova, O. P. Penezina, G. M. Fomovska and others. Bisphosphonate and phosphonate preparations were synthesized in the Institute of Organic Chemistry, NAS of Ukraine by A. M. Borisevich with the participation of professors P. S. Pelkis and M. O. Losinsky and in the Engelgardt Institute of Molecular Biology, AS of the USSR by N. B. Tarusova with the participation of P. M. Khomutov, the corresponding member of AS of the USSR. Synthesis of the polyurethane composition was realized together with a group of scientists form the Institute of High-Molecular Compounds Chemistry, NAS of Ukraine under the guidance of D.Sc. G. O. Pkhakadze. 
<smiles>O=P(O)(O)CP(=O)(O)O</smiles>

\section{Methylene bis-phosphonic acid}

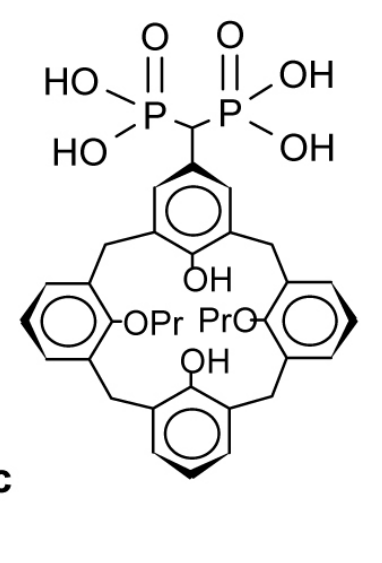

C-97<smiles></smiles>

C-192

Fig. 2. Molecular structures of methylene bisphosphonic acid, calixarene methylene bisphosphonic acid C-97 and calixarene tetrakis-methylene bisphosphonic acid C-192

This article describes the results of joint project of the Palladin Institute of Biochemistry, NAS of Ukraine and the Institute of Organic Chemistry, NAS of Ukraine focused on the synthesis, elucidation of biological activity and biopharmaceutical application of the calixarenes C-97 and C-192 functionalized with one or four biophoric methylene bisphosphonic acid groups in the upper rim (Fig. 2).

\section{Synthesis and molecular structure} of calixarene methylene bisphosphonic acids

The main method for synthesis of metylene bisphosphonic acids consists in using Arbuzov reaction of geminal dihalogenoalkanes with trialkyl phosphites followed by hydrolysis of the esters formed [1]. However, at synthesis of the calixarene methylene bisphosphonic acids, this method is limited by availability of appropriate dihalogenoalkyl calixarenes.

Calixarene methylene bisphosphonic acids C-97 [23] is synthesized from monoformyl calixarene 1 (Scheme 1). On the first stage, diethylphosphite sodium salt is added to the $\mathrm{C}=\mathrm{O}$ bond of monoformyl calixarene $\mathbf{1}$, according to the classical scheme of the Abramov reaction, with formation of $\alpha$-hydroxyphosphonate 2 . Then, in the presence of sodium, hydroxyphosphonate 2 diethyl phosphite cleaves water molecule to form a phosphorylated quinonmethyde as intermediate (omitted in the scheme). The quinonmethyde further reacts with diethyl phosphite to form calixarene methylene bisphosphonate 3. Acid C-97 is obtained by consecutive treatment of the ester 3 with trimethylbromosilane and methanol.

Calixarene tetrakis-methylene-bisphosphonic acid C-192 is synthesized by the reaction of tetraformylcalixarene $\mathbf{4}$ with sodium salt of diisopropyl phosphite with formation of tetrakis-bisphosphonate $\mathbf{5}$, which after subsequent dealkylation due to treatment with trimetylbromosilane and methanol gives C-192 (Scheme 2) [2].

According to the ${ }^{1} \mathrm{H}$ NMR spectra and molecular modeling data, the acids C-97 and C-192 adopt the cone conformations. The both conformations are stabilized by intramolecular hydrogen bonds $\mathrm{OH} \cdots \mathrm{O}$ at the lower rim of macrocycle. The conformation of C-192 is additionally stabilized by the intramolecular hydrogen bonds between distal dihydroxyphosphoryl groups of the upper rim (Fig. 3). The upper rim bonding makes the cone C-192 more regular compared with C-97 one.

Below, as examples of biological activity of calixarenes, we describe our own transdisciplinary investigations, which illustrate the use of calixarene methylene bisphosphonic acids (calix[4]arenes C-97 and C-192) as inhibitors of two separate biochemical processes: the reaction of $\mathrm{Mg}^{2+}$ dependent ATP hydrolysis, catalyzed by uterine smooth muscle myosin sudfragment-1, and the process of fibrin polymerization and formation of fibrin network of thrombus. 


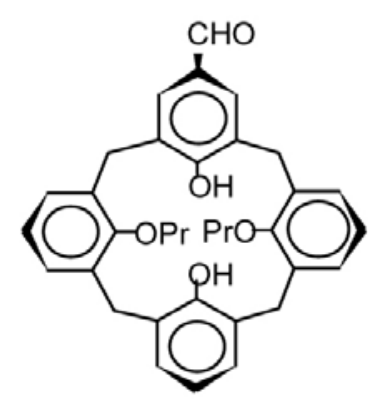

1

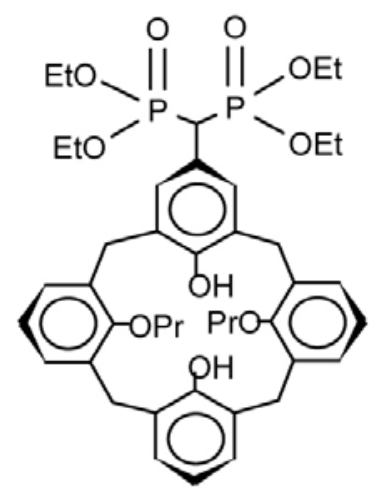

3
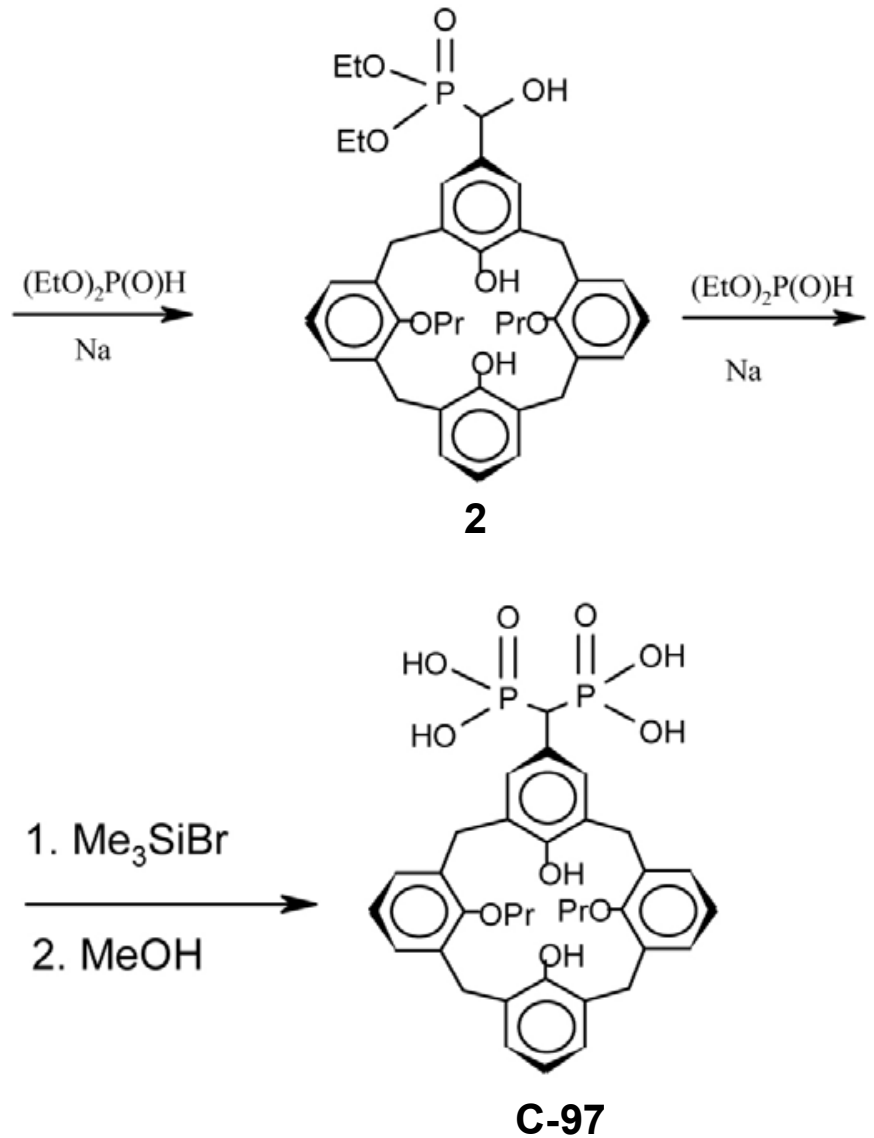

Scheme 1

\section{Structure-functional basis of intermolecular interactions of calixarene methylene bisphosphonic acid C-97 with myometrium myosin subfragment-1}

It is of importance to understand molecular and membrane mechanisms that control the contractile function of smooth muscle, in particular myometrium, in normal state and at pathological states with different disorders; therefore, investigation of these questions is rather actual. The main function of uterus in the female organism is baby carrying and delivery. Disturbance of uterine smooth muscle motility in females often leads to various pathologies - weak labour of childbirth, premature childbirth, miscarriage etc. In this connection, there is need for development of effective methods of correcting disturbed contractile activity of myometrium and, particularly, for investigations aimed at developing and examining new pharmacological highly efficient substances capable of normalizing uterine motility.

It should be noted that at present research workers of the Department of Muscle Biochemistry (Palladin Institute of Biochemistry, NAS of Ukraine) and the Department of Phosphorane Chemistry (Institute of Organic Chemistry, NAS of Ukraine) have accumulated a number of interesting experimental results concerning the influence of calixarenes on transport and enzymatic activity of membrane-associated energydependent cation-transporting systems of plasmatic membrane, sarcoplasmic reticulum and mitochondria of uterine myocytes. It was shown that some calix[4]arenes may serve as rather selective and high-affinity inhibitors of $\mathrm{Mg}^{2+}$, ATPdependent sodium pump (calix[4]arenes C-97, C-99 and C-107; $I_{0.5}<100 \mathrm{nM}$ ) and calcium pump (calix[4]arene C-90; $I_{0.5}=20-30 \mu \mathrm{M}$ ) in the plasma membrane with $\mathrm{Ca}^{2+}$-accumulation in mitochondria, which is impossible in the presence of protonofore CCCP (calix[4]arene C-91) (here codes are given for calixarene compounds). Such membrane-associated energy-dependent transport systems are directly involved in the control of intracellular cation homeostasis (first of all, $\mathrm{Ca}^{2+}$ homeostasis). Nevertheless, in case of muscles, in particular smooth ones, of great importance for maintaining processes of electro- and pharmacomechanical coupling is functioning of both cation 


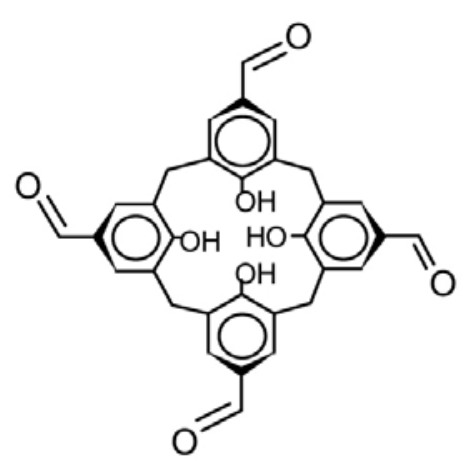

$\underset{\mathrm{Na}}{\stackrel{(\mathrm{iPrO})_{2} \mathrm{P}(\mathrm{O}) \mathrm{H}}{\longrightarrow}}$

4

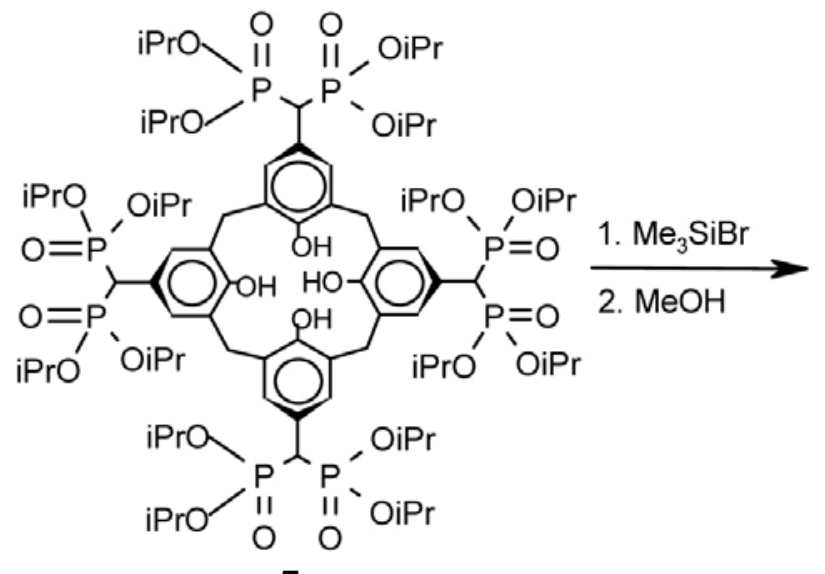

5

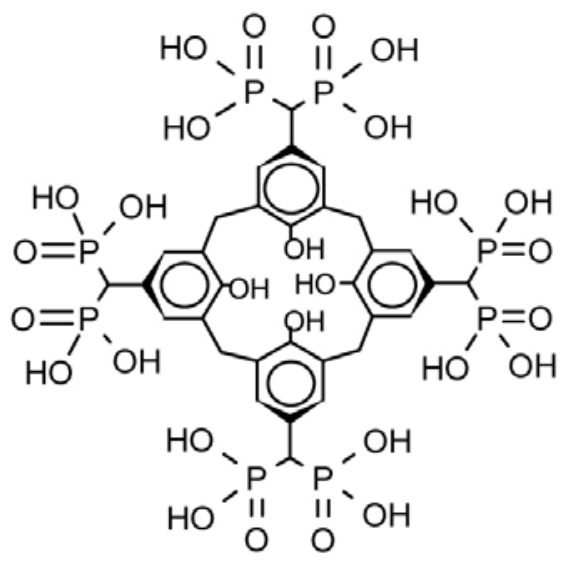

C-192

Scheme 2

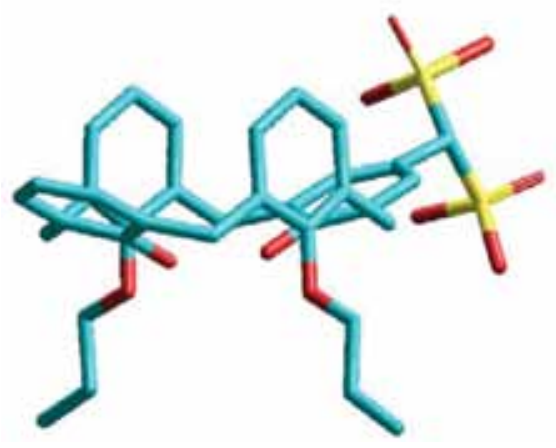

C-97

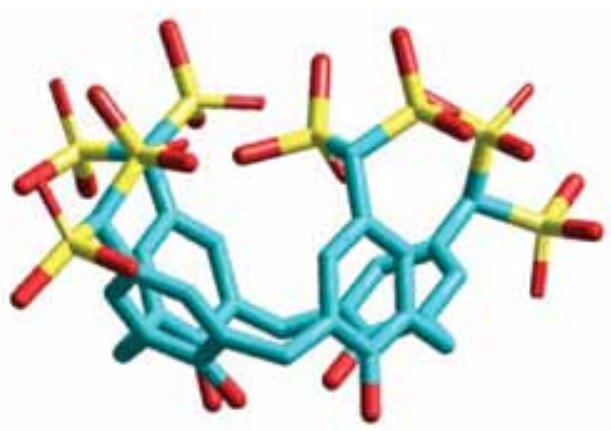

C-192

Fig.3. Energy minimized conformations of the calixarenes C-97 and C-192

transporting ATP-dependent systems and ATPhydrolase systems of contractile proteins. Different pathological states of the female reproductive system (including the ones caused by hormonal disbalance) may lead to disfunction of the uterine contractile complex, which is revealed in abnormal superprecipitation (in vitro) and changes of actomyosin ATPase activity. At some pathologies (e.g., hypertrophy) with disordered contractile function of smooth muscles, including myometrium, some changes may take place in the expression of myosin isoforms and kinetics of actin-myosin interaction. 
Accordingly, screening of reversible affine effectors of actin-myosin interaction (inhibitors, activators) is important for developing new pharmacological preparations capable of normalizing uterine contractile function at pathological state of myometrium.

Myosin ATPase transforms chemical energy, stored in ATP macroergic bonds, into mechanical work that is accompanied by directed movement; that is why this enzyme is also called a molecular motor [25]. Myosin subfragment-1 (head, S1) is Nterminal part of myosin heavy chain and consists of two domains: N-terminal globular motor (catalytic) domain, which contains an active center of ATPase, and a site of actin binding, and regulatory domain or lever-arm that is responsible for movement of myosin relative to actin.

The following functional sub-domains were identified in the structure of myosin S1: 7-stranded $\beta$-sheet (amino acid residues 116-127, 170-180, 248-257, 265-271, 458-468 and 671-678), switch 2 helix (amino acid residues 469-509), converter (amino acid residues 716-772) and SH2/SH1 hinge (amino acid residues 688-715); these sub-domains undergo substantial conformational changes during energy transfer from ATP-hydrolase centre to actin binding site [26].

ATP-binding site contains the sequence GLYGLU-SER-GLY-ALA-GLY-LYS-THR similar to sequences in active centers of other ATPases [27]. ATPase active site is formed in part by the Ploop, Switch 1 and Switch 2 polypeptides that are linked to the 7 -stranded $\beta$-sheet; conformations of these structures are sensitive to the position and coordination of $\gamma$-phosphate. ATPase center has been identified as a pocket, from which a gap is stretched to the actin binding site. When ATP binds to the myosin S1, the pocket becomes closed, while the gap expands and disturbs the binding of S1 with actin; as a result, myosin subfragment-1 dissociates from actin. When ATP is hydrolyzed by myosin ATPase to ADP and $\mathrm{P}_{\mathrm{i}}$, actin can again associate with S1, which facilitates releasing of ATP hydrolysis products from the active center. When ATP is hydrolyzed, the presence of associated actin is important for releasing of inorganic phosphate from the nucleotide-binding pocket, since in its absence the salt bridge between $\operatorname{Arg}_{238}$ (switch 1) and $\mathrm{Glu}_{459}$ (switch 2) inhibits the phosphate release $[14,28]$. Switch $2 \alpha$-helix transmits linear force (arising at ATP hydrolysis) from the active site to the converter domain; the last converts linear force into a torque that rotates the lever-arm and enables the shift of myosin relative to actin.

According to available literature, subfragment-1 is a self-sufficient functional part of myo- sin molecule; it preserves the properties of native myosin even in isolated state - that is, it displays ATPase activity and ability to interact with actin $[29,30]$.

Earlier we showed the inhibiting effect of calix[4]arene C-97 on ATPase activity of myometrium actomyosin (inhibition coefficient $\mathrm{I}_{0.5}=84 \pm 2 \mu \mathrm{M}$ ) [31]. In this connection, the question arises concerning the mechanisms of calix[4]arene C-97 effect on ATP-hydrolase activity of (exactly) myosin subfragment-1. Subfragment-1 is a convenient model for studying calixarene effects due to its high solubility in aqueous solutions with low ionic strength (unlike myosin) and because its specific ATPase activity is close to the myosin activity.

Below we provide some data obtained in the study of calix[4]arene C-97 effect on ATP-ase activity of myometrium smooth muscle myosin subfragment- 1 and consider possible mechanisms of complex formation between this calix[4]arene and myosin subfragment-1 (with the use of computer simulation techniques - doking analysis and molecular dynamics).

At first, we will give some information concerning methodological approaches used in the study.

Obtaining actomyosin and myometrium myosin subfragment-1. These studies were performed by R. D. Labintseva and O. A. Bevza (Palladin Institute of Biochemistry, NAS of Ukraine). Smooth muscle actomyosin was purified from muscle tissue of pig uterus according to Barany [32] and Weber [33] with some modifications. Myometrium smooth muscle myosin subfragment- 1 was obtained through actomyosin splitting by $\alpha$-chymotrypsin according to the method of Weeds and Taylor [34] with some modifications. Separation and purification of subfragment-1 was performed by ion exchange chromatography using column packed with DEAE-Sepharose CL-6B and chromatographic system BioRad (USA). Protein concentration was determined by Bradford method [35]; also, concentrational dependence of light absorption at $280 \mathrm{~nm}$ was used with the curve standardized by serum albumin. Purity of smooth muscle myosin subfragment-1 was controlled by electrophoresis in polyacrylamide gel with sodium dodecyl sulphate according to Laemmli electrophoretic technique [36]. In accord with electrophoretic data, myosin head had $\mathrm{Mr} \approx 100 \mathrm{kDa}$, which corresponded to literature results [37]. Subfragment-1 was identified as a fraction having a rather high ATPase activity $68 \pm 9 \mu \mathrm{mol} \mathrm{P}_{\mathrm{i}} / \mathrm{min}$ per $1 \mathrm{mg}$ of protein $(M \pm m$, $n=8)$.

Determination of ATPase activity of myometrium myosin subfragment-1. These experiments 
were done by R. D. Labintseva and O. A. Bevza (Palladin Institute of Biochemistry, NAS of Ukraine). ATPase activity of myosin subfragment-1 was measured at $37{ }^{\circ} \mathrm{C}$ in an incubation medium (total volume $1 \mathrm{ml}$ ) of the following composition (in $\mathrm{mM}$ ): tris- $\mathrm{HCl}$ buffer $(\mathrm{pH} 7.2)-20, \mathrm{KCl}-$ $100, \mathrm{CaCl}_{2}-0.01, \mathrm{MgCl}_{2}-5$, ATP -3 (standard conditions). The quantity of inorganic phosphate $\mathrm{P}_{\mathrm{i}}$ removed from ATP during hydrolase reaction was determined by Chen's method [38].

Study of calix[4]arene C-97 effect on ATPase activity of myometrium myosin subfragment-1. Kinetic measurements. These experiments were carried out by R. D. Labintseva, O. A. Bevza and S. O. Kosterin (Palladin Institute of Biochemistry, NAS of Ukraine). To study calixarene C-97 effect on ATP-ase activity of isolated myosin subfragment-1, aliquots of calixarene solution in $50 \mathrm{mM}$ tris- $\mathrm{HCl}$ buffer ( $\mathrm{pH}$ 7.2) with the initial concentration $10 \mathrm{mM}$ were added to the standard incubation medium (see above). Final calixarene concentration in the sample was $10-100 \mu \mathrm{M}$. The value of ATP hydrolase activity, determined at the absence of calixarene in the incubation medium, was taken for $100 \%$ ("zero point"). At studying concentration dependence of calix[4]arene C-97 effect on the enzymatic activity of myosin subfragment-1 ATPase, the values of the apparent inhibition coefficient $I_{0.5}$ and Hill coefficient $n_{\mathrm{H}}$ were calculated with the use of linearized Hill graphs [39] according to the empirical equation

$$
\lg \left[\left(V_{0}-V\right) / V\right]=-n_{\mathrm{H}} \cdot \lg I_{0.5}+n_{\mathrm{H}} \cdot \lg I,
$$

where $V$ is specific enzymatic activity, $V_{0}$ is specific enzymatic activity at the absence of the inhibitor in the incubation medium and $I$ is the inhibitor concentration in the incubation medium. Typical value of the correlation coefficient $r$ was 0.97-0.99.

Photon-correlation spectroscopy experiments. This research was carried out by O. Yu. Chunikhin, R. D. Labintseva and O. A. Bevza (Palladin Institute of Biochemistry, NAS of Ukraine). Photoncorrelation spectroscopy (PCS) experiments were performed on the device ZetaSizer-3 Malvern Instrument (Great Britain) equipped with the Multi computing correlator type 7032 ce. Samples were irradiated by the helium-neon laser LGN-111 $(\lambda=633 \mathrm{~nm}$, power $25 \mathrm{mw})$ and laser radiation scattered at the angle $90^{\circ}$ was registered. Computer program PCS-Size mode v.1.61 [40] was used to analyze the experimentally measured autocorrelation function and calculate the function of distribution by hydrodynamic diameter (HDD) for microparticles in the volume of the measuring cell. PCS was used to determine average HDD and the function of distribution by dimensions for particles of myometrium myosin subfragment-1 as well as for particles that are formed at interaction of myosin subfragment-1 with calix[4]arene C-97 (20, 60 та $100 \mu \mathrm{M})$.

Computer simulation of the ligand-receptor interaction in the system "calix[4]arene C-97-myosin subfragment-1". These experiments were carried out by O. V. Bevza, R. D. Labintseva and O. A. Bevza (Palladin Institute of Biochemistry, NAS of Ukraine). Computer simulation of the ligand-receptor interaction for the system "calix[4]arene C-97 - myosin subfragment-1" was performed using the softwere MVD 4.1.0. This program allowed realizing several algorithms of searching for the optimal ligand position in the active site of the protein (a variant of the evolutionary algorithm was used) [41]. Actually, docking of the ligand (calix[4]-arene C-97) into the ligand-binding site (LBS) of myosin subfragment- 1 was realized in conditions of entirely ionized methylene bisphosphonic fragment. Standard AMBER force field parameters were used for the metal ion $\left(\mathrm{Mg}^{2+}\right)$ [42]. When modeling interactions between calix[4]-arene C-97 and myometrium myosin subfragment-1, we realized so called "semiflexible" docking (only ligand motility was taken into account) with selection of a series of complexes having the lowest total energy of the ligand binding. Calculation of the optimal geometry of the complexes formed and determination of energetically most advantageous spatial arrangement of calixarene in the area of myosin molecule were performed taking into account van der Waals, electrostatic and hydrophobic interactions, hydrogen bonds as well as contribution of desolvation energy. In the investigation, there has been used three dimensional structure of myosin subfragment-1 with the identifier 1B7T in RSCB Protein Data Bank [43]. Molecular dynamics of calix[4]arene C-97 interaction with LBS of myosin subfragment-1 was investigated with the use of the Gromos96 force field [44]. The protein model has been "placed" into a virtual cell in the form of cut octahedron in such a manner that spacing from the protein to the cell walls did not exceed $1.5 \mathrm{~nm}$. The cell was "packed" with water molecule models (solvent) - SPC (Single Point Charge). The water molecules were partially substituted for $\mathrm{Na}$ and $\mathrm{Cl}$ ions to neutralize the system charge and simulate the physiological ionic strength $(0.1 \mathrm{M})$. "Counterbalancing" of the solvent molecules was carried out during $0.5 \mathrm{~ns}$ with the protein atoms "attached" to their initial coordinates. The temperature and the pressure were $298 \mathrm{~K}$ and $1 \mathrm{~atm}$, accordingly (Berendsen's method was used) [45]. Following the solvent molecule counterbalancing, additional 
minimization of the system energy has been performed. Actually, MD simulation method was realized using the same parameters as at the solvent "counterbalancing" except for limiting the protein atom motility. The coordinates were recorded into the initial trajectory file every 10 picoseconds. Motility of the calix[4]arene C-97 molecule in the course of molecular dynamics was visualized with the use of the program UCSF Chimera 1.5.3 [46].

\section{II.1. Investigation by photon correlation spectroscopy of calix[4]arene C-97 effect on the effective hydrodynamic diameter (HDD) of isolated myosin subfragment-1}

PCS method gives distribution of different molecules and supramolecular structures in solution by their sizes. To determine HDD by PCS method, Stokes-Einstein formula is used that is valid only for spherical particles $[47,48]$. Therefore, molecular diameters determined by this method will be close to the real ones only for globular proteins. When a protein is far from spherical form, calculated HDD is a rather conventional value.

Myosin head, main functional unit of myosin [49], is rounded or pear-shaped [16]; therefore, the preparation of isolated myometrium myosin subfragment-1 fits rather well for studying by PCS method the effect of calix[4]arene on contractile proteins. There were determined average subfragment-1 HDD and the function of particle size distribution. Isolated myosin subfragment-1 had narrow spectrum of particles in the interval from approximately 10 to $50 \mathrm{~nm}$ (Fig. 4). The size of most frequently registered particles $(\approx 50 \%)$ was close to $20 \mathrm{~nm}$. There were also present in small quantity particles with diameter close to $70 \mathrm{~nm}$ and particles less then $20 \mathrm{~nm}$. It was shown that the average (most probable) HDD of myosin subfragment-1 was $22 \pm 3 \mathrm{~nm}(M \pm m ; n=15)$. This value fits to the literature data $[50,51]$.

Concentration dependence of calix[4]arene C-97 effect on the hydrodynamic indices of myosin subfragment-1 particles showed that calix[4]-arene concentrations 20 and $60 \mu \mathrm{M}$ did not cause significant changes of myosin head HDD vs. control only trend in HDD growth was observed. Only at calix[4]arene concentration of $100 \mu \mathrm{M}$, myosin head HDD reliably increased versus control: from $22 \pm 3 \mathrm{~nm}$ (control) to $33 \pm 3 \mathrm{~nm}$ (experiment) (Fig. 5). Control examination of calix[4]arene C-97 solution in $50 \mathrm{mM}$ tris- $\mathrm{HCl}(\mathrm{pH} \mathrm{7.2)}$ failed to discover any light scattering microparticles.

Thus, calix[4]arene C-97 at a concentration of $100 \mu \mathrm{M}$ caused a significant (vs. control) increase of myosin subfragment-1 HDD, which indicated the formation of a complex between calix[4]arene and myosin head.

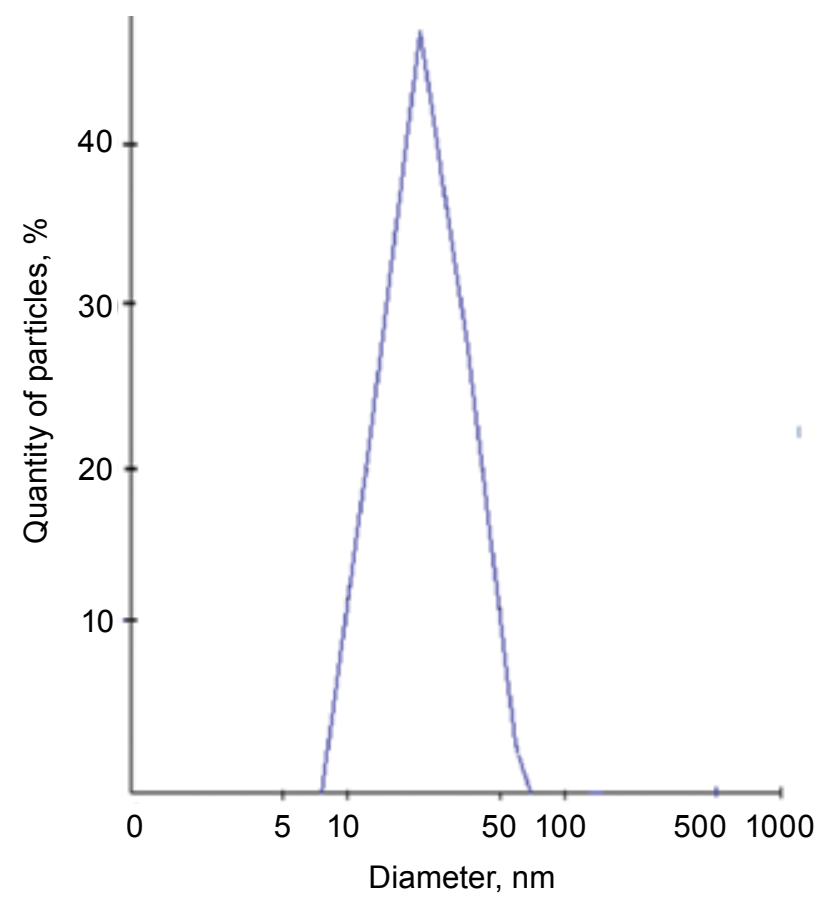

Fig. 4. The hydrodynamic diameter (HDD) distribution for myosin subfragment-1 particles. Photoncorrelation spectroscopy method. The quantity of particles, equivalent HDD of which corresponded to the values in the interval from $H D D_{\text {min }}$ to $H D D_{\max }$ with the accuracy $0.1 \%$ (according to the characteristics of the laser-correlation spectrophotometer), was taken for $100 \%$. In the Figure, a typical experimental result is shown

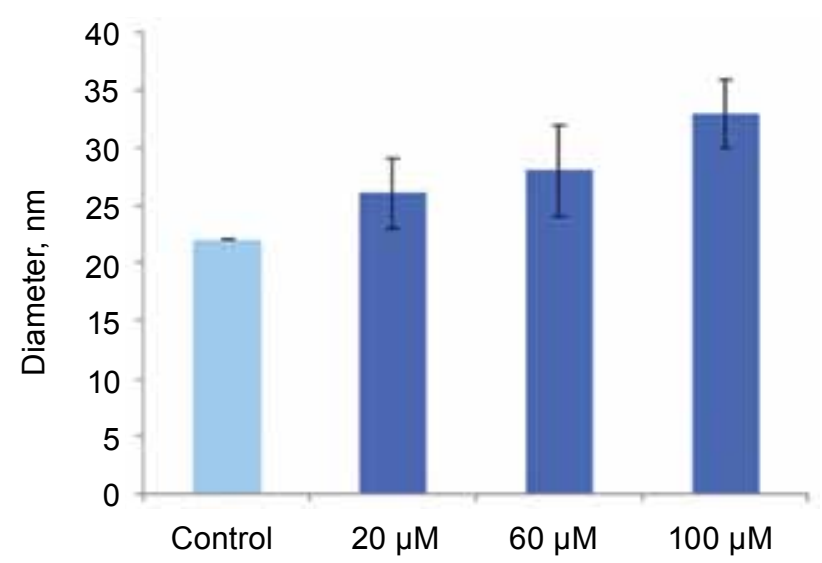

Fig. 5. Calix[4]arene C-97 increases the myosin subfragment-1 hydrodynamic diameter (HDD) $(M \pm m$; $n=6)$. Photon-correlation spectroscopy method

Of interest is the fact that using photon correlation spectroscopy with other supramolecular effector (activator) of myosin subfragment-1 ATPhydrolase (calix[4]arene C-107), we could observe time dependent changes of myosin subfrag- 
ment-1 HDD (data are not given). During the first 5 min after calix[4]arene $\mathrm{C}-107$ addition $(60 \mu \mathrm{M})$, values of HDD increased from $25 \mathrm{~nm}$ (control) to 70-80 $\mathrm{nm}$, but the next 10 to $15 \mathrm{~min}$ the size of myosin head was stabilized at the HDD values of $45 \mathrm{~nm}$ (which is undoubtedly more vs. control).

\section{II.2. Examination of calix[4]arene \\ C-97 effect on ATPase activity \\ of myometrium myosin subfragment-1}

Study of calix[4]arene C-97 effect on myometrium myosin subfragment-1 ATPase showed that in concentration of $10 \mu \mathrm{M}$ it almost did not influence ATPase activity. At further increase of this calixarene concentration, it inhibited myosin head ATPase in dose-dependent mode and at $100 \mu \mathrm{M}$ concentration the inhibiting effect vs. control was $60 \pm 5 \%(M \pm m ; n=5)$ (Fig. 6). According to the linearized graph in Hill coordinates (Fig. 6, 7), inhibition coefficient $I_{0.5}=83 \pm 7 \mu \mathrm{M}$ $(M \pm m ; n=5)$.

When comparing calix[4]arene C-97 inhibition of ATPase activity for actomyosin complex $\left(I_{0.5}=84 \pm 2 \mu \mathrm{M}\right)$ [52] and myometrium myosin subfragment-1 $\left(I_{0.5}=83 \pm 7 \mu \mathrm{M}\right)$, one can see that myosin head and actomyosin complex display practically identical affinity towards this calix[4] arene. Of interest is the fact that $\mathrm{Na}^{+}, \mathrm{K}^{+}$-ATPase of plasmatic membranes [40] has several orders of magnitude higher affinity for calix[4]arene C-97 $\left(I_{0.5}=98 \pm 8 \mathrm{nM}\right)$ as compared with actomyosin and myosin subfragment-1 ATPase [19]. This ob-

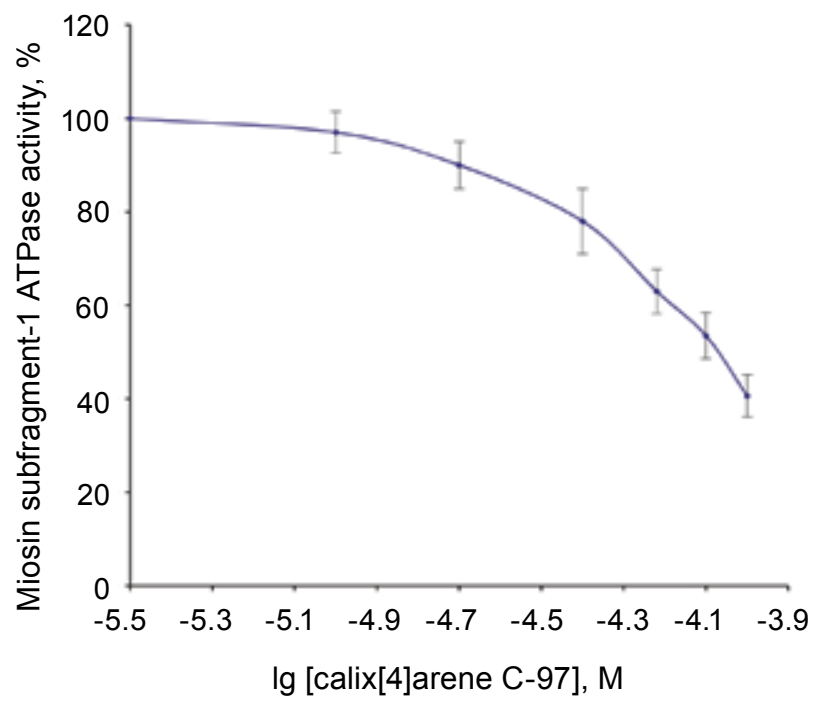

Fig. 6. Catalytic titration of myosin subfragment-1 ATPase activity with calix[4]arene C-97 (M $\pm \mathrm{m}$; $n=5$ ) servation should be taken into account at analysis of calix[4]arene C-97 effect on contractile and electric activity of smooth muscle cells.

Using linearized graphs at analysis of concentration dependence of subfragment-1 ATPase activity on calix[4]arene C-97, we also calculated Hill coefficient $n_{\mathrm{H}}$, which amounts to $1.3 \pm 0.5$ (Fig. 7). Therefore, this value of Hill coefficient most probably suggests that myosin head may bind only one molecule of calix[4]arene C-97.

Therefore, calix[4]arene C-97 effect on ATPase of contractile complex may follow from its ability to bind with myosin subfragment-1; consequently, myosin head is supposed to be one of targets by means of which calix[4]arene C-97 may influence the contractile complex (based on the above value of Hill coefficient $n_{\mathrm{H}}$, the stoichiometry of binding is $1: 1$ ).

II.3. Using the computer simulation method for examining the structural basis of molecular interactions between calix[4]arene C-97 and myometrium myosin subfragment-1

To understand the molecular mechanism of calix[4]arene C-97 inhibiting effect on myosin subfragment-1 ATPase, it needs to have information on three-dimensional structure of the enzyme in complexes with substrate or/and inhibitor. With this purpose, we carried out the computer simulation for the interaction of calix[4]arene C-97 (as a separate ligand or coupled with ATP) with myometrium myosin subfragment-1 in the presence of

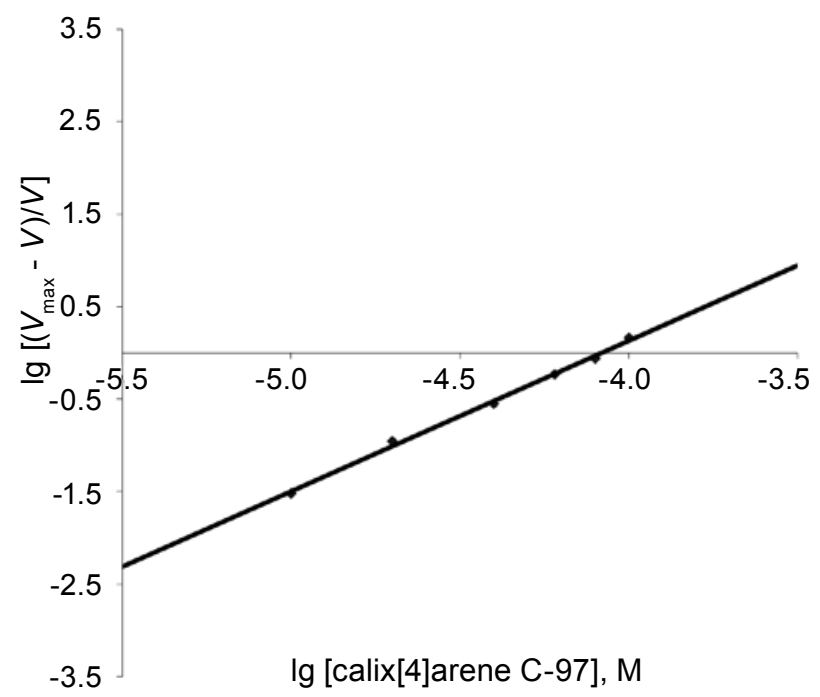

Fig. 7. Averaged curve linearized in Hill coordinates for catalytic titration of myosin subfragment-1 ATPase activity with calix[4]arene $\mathrm{C}-97$ 

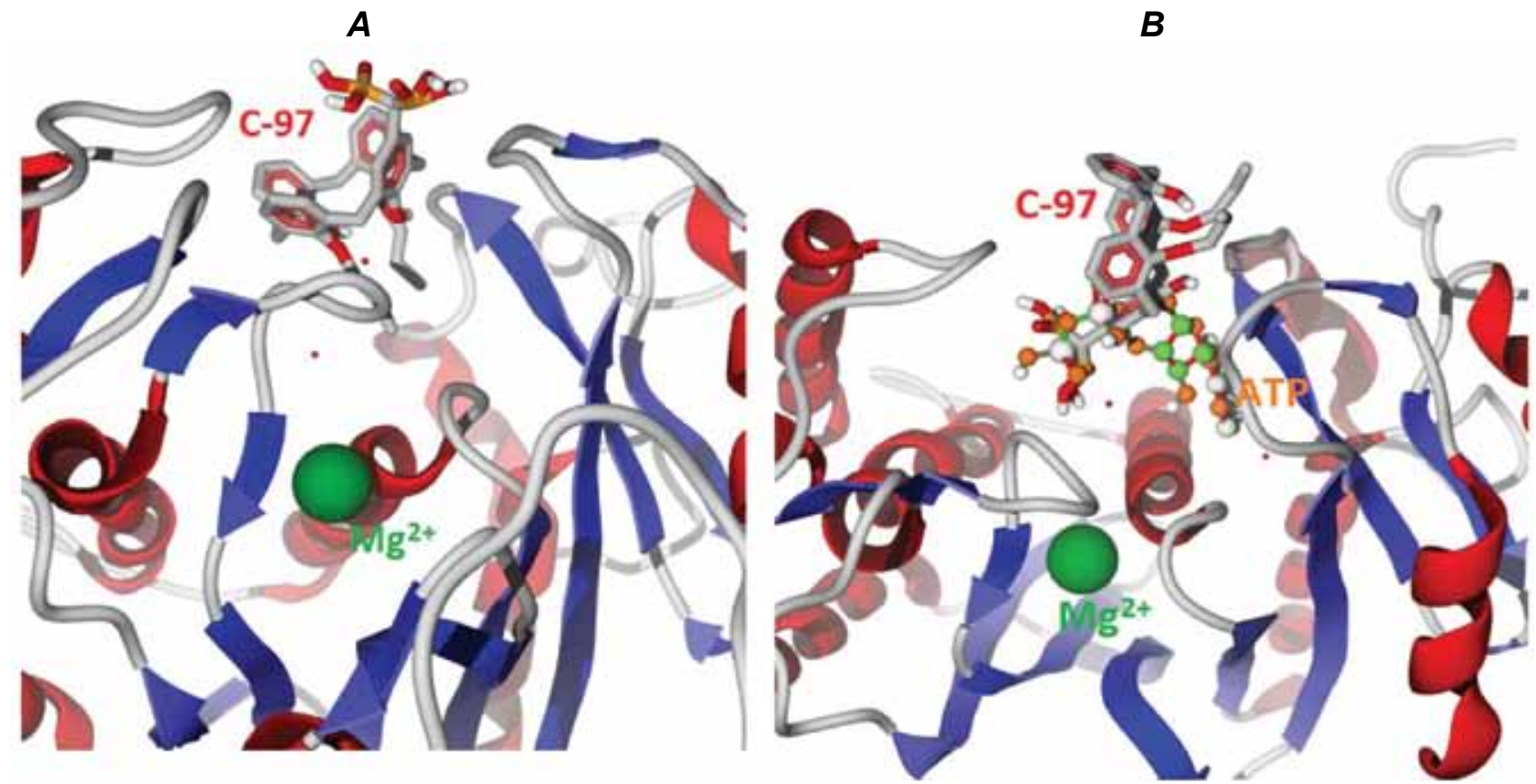

Fig. 8. Docking of calix[4]arene C-97 as a separate ligand into the active site of myosin subfragment-1 (A) and docking of the paired ligand "calix[4]arene C-97+ATP" $(\boldsymbol{B})$ at the presence of $\mathrm{Mg}^{2+}$ as a cofactor

$\mathrm{Mg}^{2+}$ as a cofactor (Fig. $\left.8, A, B\right) . \mathrm{Mg}$ cation takes part in binding of ATP to the active site and in the process of its hydrolysis.

An analysis of docking of calix[4]arene C-97 as a separate ligand into the ligand binding site of myosin subfragment-1 suggests that residues Asp $_{320}$, $\mathrm{Asn}_{321}, \mathrm{Leu}_{676}$ and $\mathrm{Gln}_{678}$ may be involved in fixation of calix[4]-arene phosphonate groups (the data are not shown in the Figure). Calixarene fragments are oriented in the space formed by residues $\mathrm{Ile}_{322}$, $\mathrm{Asn}_{238}$ and $\mathrm{Lys}_{677}$ on one side, and by $\mathrm{Tyr}_{12} 6, \mathrm{Arg}_{127}$ and $\mathrm{Arg}_{128}$ on the other. Besides, positively charged nitrogen atom of $\mathrm{Lys}_{677}$ residue is located next to oxygen atoms of methylene bisphosphonate fragment (distance between nitrogen atom of $\mathrm{Lys}_{677}$ residue and ionized oxygen atoms of the phosphonate group is $0.31 \mathrm{~nm}$ ). There were indentified bonds taking part in calix[4]arene binding to a site close to the active centre of myosin S-1; they are: hydrogen bonds, $\pi$ - $\pi$-stacking interactions between aromatic fragments of calix[4]arene bowl and $\mathrm{Tyr}_{126}$ of benzene ring in myosin head as well as electrostatic interactions with involvement of $\mathrm{Arg}_{127}$, $\operatorname{Arg}_{128}, \operatorname{Asp}_{320}$ and $\mathrm{Lys}_{677}$.

Simultaneous docking of the paired ligand "calix[4]arene C-97 + ATP" into the ligand binding centre of myosin subfragment-1 in the presence of $\mathrm{Mg}^{2+}$ revealed the possible formation of a complex between calix[4]arene C-97 and ATP, which binds with involvement of amino acid residues to a site of myosin head close to the active centre; this is somewhat different from results obtained with docking of calix[4]arene C-97 alone. In addition, spatial orientation of calix[4]arene C-97 in the ligand binding centre of myosin head differs: methylene bisphosphonate fragment of calix[4]arene at its interaction with ATP molecule becomes oriented towards the active centre. Binding of the complex "calix[4]arene C-97 + ATP" to a site close to the myosin S1 active centre is realized with participation of hydrogen bonds, $\pi$ - $\pi$-stacking interactions between aromatic rings of calix[4]arene bowl and benzene rings of $\mathrm{Tyr}_{126}$ and $\mathrm{Tyr}_{132}$ in myosin head as well as electrostatic interactions with participation of $\mathrm{Arg}_{127}$. Residues $\mathrm{Asn}_{238}$ and $\mathrm{Asn}_{321}$, which are rather close to oxygen atoms of phosphonate groups, may form hydrogen bonds at interaction with ligand phosphonate groups. It is also obvious that hydrophobic platform of functionalized calix[4]arene C-97 may contribute to the binding due to the interaction with hydrophobic sites in the centre of substrate binding.

Table 1 shows amino acid residues of the active centre of myometrium myosin S1, which are involved in interactions with calix[4]arene C-97 and the complex "calix[4]arene C-97 + ATP". According to literature, residues $\mathrm{Tyr}_{126}, \mathrm{Arg}_{127}, \mathrm{Leu}_{676}$ and Lys $_{677}$, enabled in fixation of calix[4]arene C-97 phosphonate groups, are incorporated into the 7 -stranded $\beta$-sheet structure of myosin subfragment-1, which is joined with polypeptide sites switch 1 and switch 2 . These polypeptides partici- 
Table 1. Amino acid residues of the substrate binding domain of myosin subfragment-1, which take part in binding of calix[4]arene C-97 in the case of its docking as a separate ligand and when docking is performed for a couple of ligands "C-97 + ATP" in the presence of $\mathrm{Mg}^{2+}$ as cofactor

\begin{tabular}{c|c}
\hline $\mathrm{C}-97+\mathrm{Mg}^{2+}$ & $\mathrm{C}-97+\mathrm{ATP}+\mathrm{Mg}^{2+}$ \\
\hline $\mathrm{Tyr}_{126}$ & $\mathrm{Asn}_{124}$ \\
$\mathrm{Arg}_{127}$ & $\mathrm{Pro}_{125}$ \\
$\mathrm{Arg}_{128}$ & $\mathrm{Tyr}_{126}$ \\
$\mathrm{Asn}_{238}$ & $\mathrm{Arg}_{127}$ \\
$\mathrm{Asp}_{320}$ & $\mathrm{Tyr}_{132}$ \\
$\mathrm{Asn}_{321}$ & $\mathrm{Glu}_{184}$ \\
$\mathrm{Ile}_{322}$ & $\mathrm{Asn}_{185}$ \\
$\mathrm{Leu}_{676}$ & $\mathrm{Asn}_{238}$ \\
$\mathrm{Lys}_{677}$ & $\mathrm{Asn}_{321}$ \\
$\mathrm{Gln}_{678}$ & $\mathrm{Ile}_{322}$ \\
\hline
\end{tabular}

pate directly in the ATPase active centre formation [14]. Therefore, it is obvious that interaction of calix[4]-arene C-97 with myosin subfragment-1 in the site located near the ATPase centre of myosin will influence this centre conformation and, accordingly, the process of ATP hydrolysis catalyzed by myosin subfragment-1.

Therefore, the results obtained by the method of molecular docking indicate that: 1) calix[4]arene C-97 may bind with myosin subfragment-1 to the site close to the active centre, which leads to conformational changes in the last; 2) this calix[4]arene may form a complex with ATP prior to the interaction with the protein, which complicate access of nucleoside triphosphate to the ATP binding site. It may well be that both these variants of calix[4]arene C-97 interaction with subfragment-1 may cause their inhibiting effect on ATPase activity of myometrium myosin subfragment-1. Nevertheless, it should be noted that the last variant cannot explain considerable differences (almost three orders of magnitude) between affinity towards calix[4]arene C-97 for $\mathrm{Na}^{+}, \mathrm{K}^{+}$-ATPase and myosin subfragment-1 ATPase (values of inhibition coefficient $I_{0.5}$ is equal $100 \mathrm{nM}$ [29] and $80-90 \mu \mathrm{M}$, respectively).

Note that the docking method fails to take into account motility of myosin S1 and ligands, which may occur in real conditions. Therefore, to verify results obtained by the docking method, we investigated interaction of calix[4]arene C-97 with the ligand binding centre of myosin subfragment-1 by the method of molecular dynamics taking into consideration the motility of both the receptor (myosin subfragment-1) and the ligand.

The dynamic analysis of the calix[4]arene C-97 molecule position in the ligand binding site of myosin subfragment-1 allowed to determine time dependent deflections of the active site atoms from their initial state; this deflections were characterized by changes of distances (in $\mathrm{nm}$ ) between calix[4]arene centre of mass and the nearest amino acid residue $\left(\mathrm{Asn}_{321}\right)$. Accordingly, there was plotted (at intervals of $4 \mathrm{~ns}$ ) time dependence of C-97 position in the ligand binding site of myosin subfragment-1. Analysis of the deflections showed that initial calix[4]arene location was changing noticeably starting approximately from $1 \mathrm{~ns}$ : calix[4]arene conformational mobility increased and afterwards again decreased, which correlated with the change of distance between calix[4]arene and $\mathrm{Asn}_{321}$ centers of mass. Therefore, the interaction of calix[4] arene C-97 with myosin head is accompanied by time variation of calix[4]arene location. In the process of molecular dynamics, the total energy of the system "calix[4]arene C-97 - myosin subfragment-1" becomes somewhat lower; therefore, calix[4]arene C-97 apparently takes up a more energy advantageous position in the ligand binding site of myosin subfragment-1. It was shown that calix[4]arene C-97 molecule shifts relative to amino acid residue $\mathrm{Asn}_{320}$ by about $1.81 \AA$ and that arrangement of calix[4]arene C-97 in the final binding location is stable energetically.

The analysis of hydrogen bonds during 4 ns interval between calix[4]-arene C-97 and amino acid residues of the subfragment-1 ligand binding site (Fig. 9) shows that the number of hydrogen bonds enabled in the interaction between calix[4]arene C-97 and myosin head remains on the average unchanged. Consequently, calix[4] arene location changes in the course of molecular dynamicsshould be most probably caused by optimization of hydrophobic and electrostatic interactions.

The method of 4 ns molecular dynamics was also used to identify amino acid residues taking part in calix[4]arene binding to the ligand binding centre of myometrium myosin subfragment-1 (Fig. 10). They include $\operatorname{Tyr}_{126}, \operatorname{Arg}_{127}, \operatorname{Leu}_{676}$ and Lys $_{677}$. These residues take part in fixation of calix[4]arene phosphonate groups that are located, according to literature [14], next to the ATPase active centre. Overall, these results correlate well with the data obtained by the docking method (see above).

The computer simulation results broadened out our notions about the structural basis of intermolecular interactions between calix[4]arene 


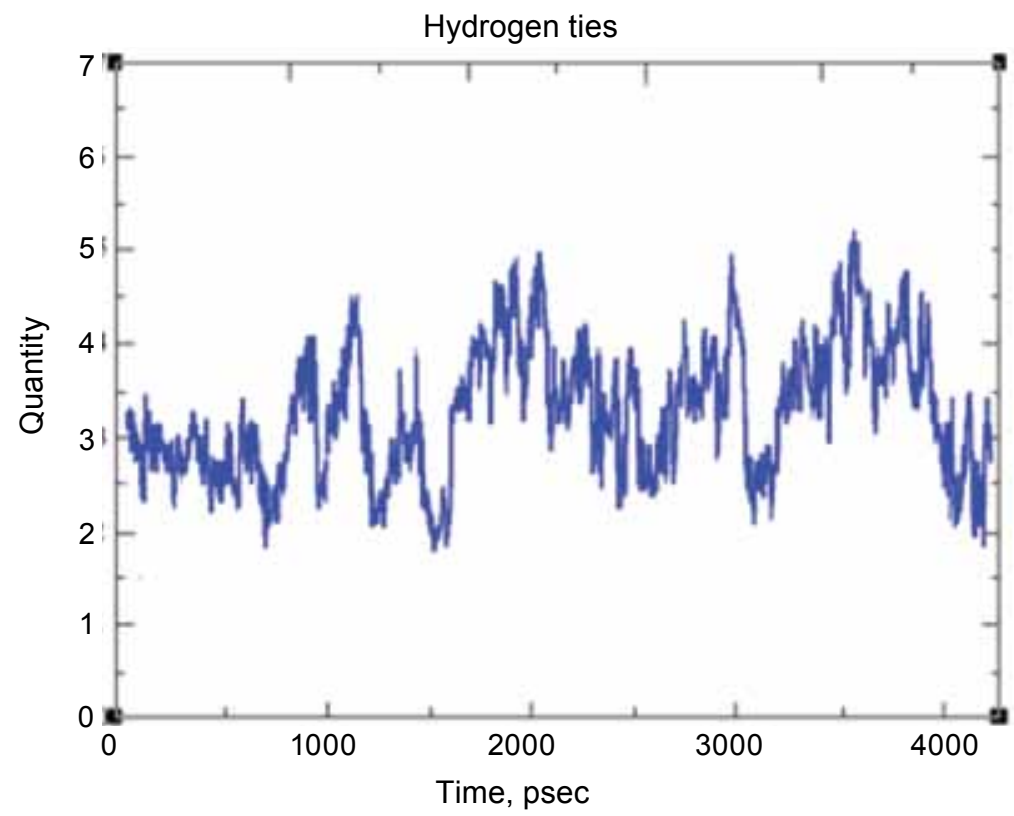

Fig. 9. Dynamics of hydrogen bonds generated between calix[4]arene C-97 and amino acid residues of the ligand binding centre of the myosin subfragment-1

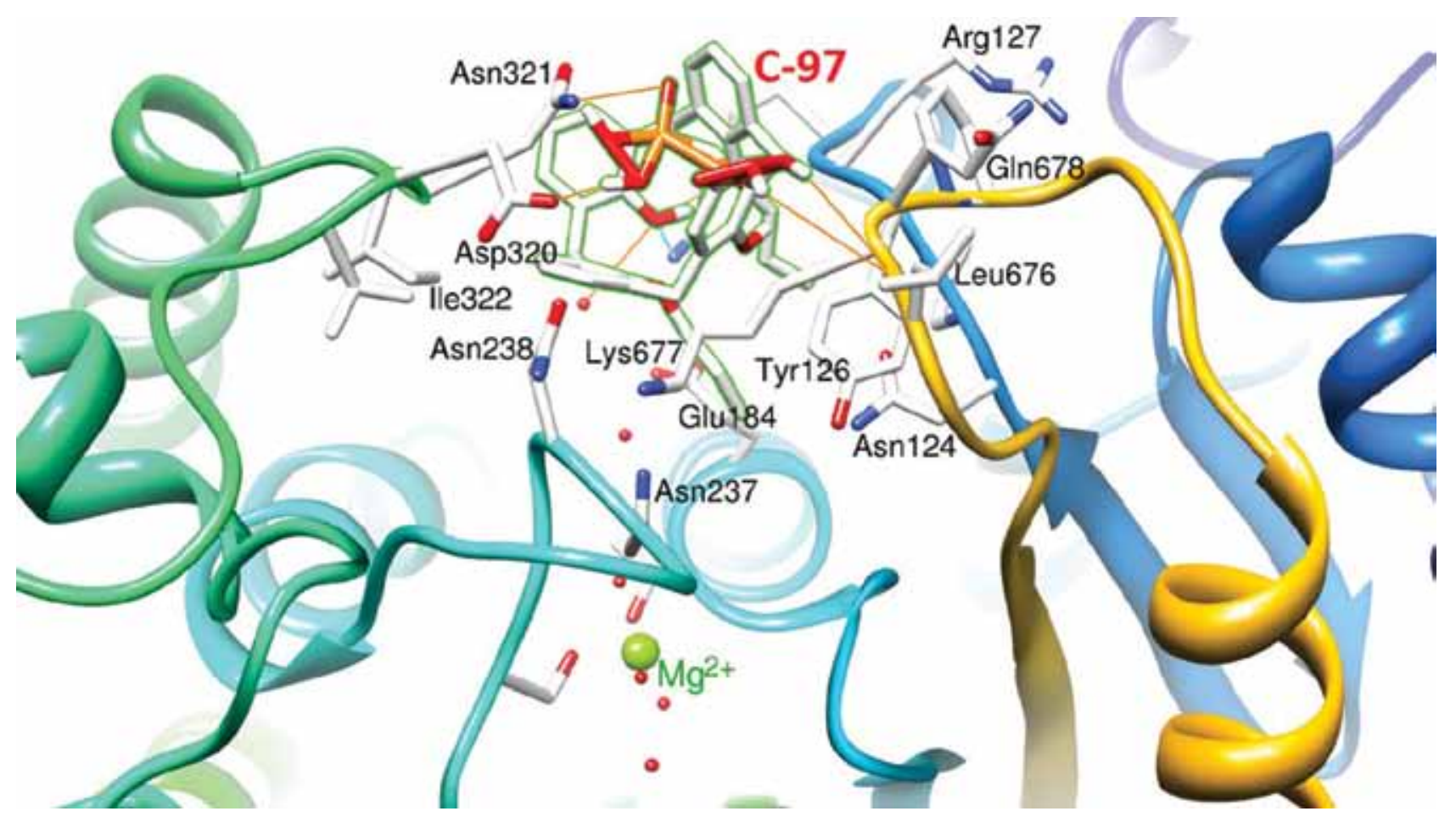

Fig. 10. Binding of calix[4]arene C-97 in the ligand binding centre of myosin subfragment-1 determined by 4 ns molecular dynamics. The Figure shows amino acid residues taking part in calix[4]arene binding to LBC of myosin subfragment-1. Dotted lines show H-bonds between amino acid residues of subfragment-1 and the inhibitor. Interactions of $C-97$ with myosin head include also $\pi-\pi$ stacking interactions and electrostatic bonds

C-97 and myometrium myosin subfragment-1. In particular, there was elucidated the role of hydrophobic, electrostatic and $\pi$ - $\pi$-stacking interactions between calix[4]arene and amino acid residues of myosin subfragment-1, some of which are close to ATPase active centre.

Thus, calix[4]arene C-97 inhibits effectively ATPase activity of myosin subfragment-1 
$\left(I_{0.5}=83 \pm 7 \mu \mathrm{M}\right)$. This substance causes statistically significant (vs. control) increase of the myosin head hydrodynamic diameter, which is indicative of a complex formation between calixarene and myosin head. The use of the computer simulation method resulted in identification of amino acid residues, hydrophobic and electrostatic forces that take part in interactions between calix[4]arene and myometrium myosin subfragment- 1 . The results obtained suggest that myosin head is one of targets for calixarene effect on contractile complex of smooth muscle.

III. Calix[4]arene methylene bisphosphonic acids as inhibitors of fibrin polymerization

The present study aimed to investigate the anticoagulant properties of phosphorus contained calix[n]arenes [24, 53] in the last two steps of blood coagulation: thrombin+fibrinogen reaction and fibrin monomer polymerization, which lead to formation of fibrin network of thrombus. Fibrinogen is a glycoprotein $(\mathrm{MW} \approx 344 \mathrm{kDa}$ ) composed of two monomeric units connected by disulfide bonds. Each monomer consists of three non-identical polypeptide chains $\mathrm{A} \alpha, \mathrm{B} \beta$ and $\gamma$, also connected by disulfide bridges [54]. The $\mathrm{NH}_{2}$-terminal ends of all six polypeptide chains are situated in the central region of fibrinogen known as the E-region. Two peripheral regions of the molecule historically are called the D-region.

When blood coagulation system is activated, thrombin is formed from prothrombin and attacks fibrinogen, splitting off two fibrinopeptides A (A $\alpha 1-16)$, and thereby exposing fibrin polymerization sites 'A' (Aa17-19) [55]. Removal of fibrinopeptides A leads to a form of fibrinogen deemed 'desA', which polymerizes spontaneously to form two-molecule thick protofibrils. Removal of fibrinopeptides B ('desAB') encourages lateral associations that lead to fibrils $[56,57]$. The fibrils continue to associate, branching and forming a 3D network: the framework of the blood thrombus [58]. It is widely accepted that the initial step of fibrin polymerization (protofibril formation) is carried out by the intermolecular pairing of ' $A$ ' and 'a' polymerization sites of fibrin monomers. Site ' $a$ ' is a cavity ('hole') that includes amino acid res-idues $\gamma \mathrm{Gln}_{329}, \gamma \mathrm{Asp}_{330}, \gamma \mathrm{His}_{340}$ and $\gamma \mathrm{Asp}_{364}$, and is located in the $\gamma \mathrm{C}$-domain of the fibrinogen/fibrin molecule [59].

In particular, we have focused on compounds in which the molecular scaffold is decorated with methylene-bis-phosphonic acid groups. One of these, calix[4]arenetetrakis-methylene-bis-phosphonic acid (C-192), has four such substituent groups (Fig. 2).
The experimental data presented in the following part of the article were carried out by the research workers of the Department of Protein Structure and Function (Palladin Institute of Biochemistry, NAS of Ukraine) and the Department of Phosphorane Chemistry (Institute of Organic Chemistry, NAS of Ukraine).

Preparation of fibrinogen, fibrin $\operatorname{des} A B$. These studies were performed by G. K. Gogolinska and T. A. Pozniak (Koshel) (Palladin Institute of Biochemistry, NAS of Ukraine). Human fibrinogen was prepared by sodium sulphate precipitation from human plasma [60] DesAB fibrin monomer was prepared as described previously [61].

Turbidity analysis of fibrin polymerization. These experiments were carried out by T. A. Pozniak (Koshel), P. G. Gritsenko and E. V. Lugovskoy (Palladin Institute of Biochemistry, NAS of Ukraine). The effects of compounds on fibrin polymerization were studied spectrophotometrically at $350 \mathrm{~nm}$ as described previously [62]. The curve of increasing turbidity during fibrin clotting shows the parameters: $\tau$, lag time, which corresponds to the time of protofibril formation; $V_{\max }$, maximum rate of fibrin polymerization, which was defined by graphic calculation of the angle of the tangent to the turbidity increase curve at the point of maximum steepness; and $\Delta \mathrm{h}$, final turbidity of fibrin clots. The polymerization of desAB fibrin was studied at its final concentration $0.1 \mathrm{mg} \cdot \mathrm{mL}^{-1}$ in the polymerization medium containing $0.05 \mathrm{M}$ ammonium acetate $(\mathrm{pH}$ 7.4) with $0.1 \mathrm{M} \mathrm{NaCl}$ and $1 \cdot 10^{-4} \mathrm{M} \mathrm{CaCl}_{2}$. The polymerization of fibrin formed in the fibrinogen + thrombin reaction was investigated at a final concentration of fibrinogen of $0.1 \mathrm{mg} \cdot \mathrm{mL}^{-1}$ and thrombin of $0.4 \mathrm{NIH}$ units. $\mathrm{mL}^{-1}$ in the same polymerization medium.

Electron microscopy. These experiments were done by T. A. Pozniak (Koshel), P. G. Gritsenko and V. I. Chernishov (Palladin Institute of Biochemistry, NAS of Ukraine). The samples of polymerizing fibrin produced in the thrombin-fibrinogen reaction in the absence or presence of calixarene C-192 $\left(10^{-5} \mathrm{M}\right)$ were taken out of the reaction medium at various times, placed on a carbon-coated grid for $2 \mathrm{~min}$ and then stained with $1 \%(\mathrm{w} / \mathrm{v})$ uranyl acetate for $1 \mathrm{~min}$. Transmission electron microscopy was performed with an H-600 electron microscope (Hitachi, Tokyo, Japan) operated at $75 \mathrm{kV}$. Electron micrographs were obtained at $\times 50000$ magnification.

The determination of association constants by the RP-HPLC method. These experiments were done by S. O. Cherenok, O. I. Kalchenko and V. I Kalchenko (Institute of Organic Chemis- 
try, NAS of Ukraine). The HPLC consisted of a high-pressure pump (type HPP 4001) (Laboratorni Pristroje, Prague, Czech Republic) connected to a Rheodyne sample 7120 injector (Rheodyne, Berkeley, CA, USA) and an ultraviolet-visible detector (type LCD 2563) (Laboratorni Pristroje). The column $(150 \cdot 3.3 \mathrm{~mm}$ inner diameter) was packed with Separon SGX CN (Lachema, Prague, Czech Republic). The mobile phase was a mixture of methanol-water in the ratio $50: 50(\mathrm{v} / \mathrm{v})$, with the calixareneC-192additive at a concentration in the range $1.48 \cdot 10^{-4}$ to $5 \cdot 10^{-4} \mathrm{M}$. The flow rate was $0.6 \mathrm{~mL} \cdot \mathrm{min}^{-1}$. The concentration of the guests/analytes in solution for analysis was $10^{-5} \mathrm{M}$. The solvent was identical to the mobile phase composition. The amount of the sample injected was $0.51 \mathrm{~L}$. Each of the samples was analyzed five times. All chromatograms were obtained at $20^{\circ} \mathrm{C}$. Association constants of the calixarene complexes with amino acids Gly, Pro, Arg and tetrapeptyde Gly-Pro-Arg-Pro (280-3395 $\mathrm{M}^{-1}$ ) were calculated from the dependence of the $1 / \mathrm{k}^{\prime}$ value versus the calixarene concentration $[\mathrm{CA}]$ in the mobile phase by Eqn (1) (Table 2):

$$
K_{\mathrm{A}}=\frac{\mathrm{k}_{0}^{\prime}\left(1 / \mathrm{k}^{\prime}-1 / \mathrm{k}_{0}^{\prime}\right)}{[\mathrm{CA}]} \text {. }
$$

Where $\mathrm{k}_{0}{ }^{\prime}$ and $\mathrm{k}^{\prime}$ are the capacity factors determined in the absence and presence of the calixarene in the mobile phase and [CA] is the calixarene concentration in the mobile phase.

$P T$ and APTT assays. These experiments were carried out by T. A. Pozniak (Koshel) and P. G. Gritsenko (Palladin Institute of Biochemistry, NAS of Ukraine). The effects of calixarene $\mathrm{C}-192$ on the coagulation of human blood plasma were studied using a coagulometer (CT 2410 'Solar', Minsk, Belarus). Reagents from Renam (Moscow, Russia) were used to calculate PT and APTT. PT and APTT ratios were calculated using the formula: $t_{c} / t_{o}$, where $t_{o}$ is the time of clot formation in blood plasma without calixarene C-192 and $t_{c}$ is the time of clot formation in blood plasma with calixarene C-192.

Calix[4]arene methylenebisphosphonic acids as inhibitors of fibrin polymerization

C-192 was studied with respect to its effects on fibrin polymerization in two kinds of assay. In the first assay, the formation of fibrin followed directly after the addition of thrombin. In the second assay, previously prepared fibrin was dispersed and then allowed to repolymerize under appropriate conditions. In both cases, fibrin formation was gauged by turbidity measurements.
Turbidity analysis showed that the compound decreased the maximum rate of fibrin polymerization in the thrombin-fibrinogen reaction by $50 \%$ at a molar ratio of compound to starting fibrinogen of 1.7 : 1 (Fig. 11). The final turbidity of clots was decreased by $50 \%$ at a molar ratio of $4.3: 1$ (compound : starting fibrinogen) (Fig. 11, C). The lagtime was also increased strongly in the presence of C-192, indicating either a decrease of the rate of protofibril formation or, conceivably, an increase of protofibril critical length (Fig. 11, B). Similar results were obtained when calixarene C-192 inhibited the re-association of dispersed desAB fibrin (Fig. $12, A-C$ ); in this case, $\mathrm{IC}_{50}=1.26 \cdot 10^{-6} \mathrm{M}$.

Such a strong and specific inhibition by calixarene C-192 of both the thrombin-fibrinogen reaction and the re-association of fibrin des $A B$ indicates that calixarene retards clotting not as a result of the inhibition of thrombin, but entirely because of the blocking of fibrin polymerization sites.

We also performed electron microscopy studies to determine the stage of fibrin polymerization that was inhibited by C-192. Transmission electron microscopy of the thrombin + fibrinogen media showed that fibrin remained in monomer state in the presence of calixarene C-192 at its final concentration of $10^{-5} \mathrm{M}$, whereas, at the same time, mature fibrils were formed in the absence of C-192 (Fig. 13).

The results of turbidity analysis and electron microscopy indicate that the inhibition by C-192 occurs at the first stage of fibrin polymerization, presumably by blocking one of the sites of protofibril formation.

We also investigated the inhibitory effects of two structural fragments of C-192: para-hydroxyphenyl-methylene-bis-phosphonic acid (1) and methylene-bis-phosphonic acid (2) (Fig. 14). The results showed that these constituents inhibit fibrin polymerization with considerably less activity: the

Table 2. Concentration values of compounds that cause $50 \%$ inhibition of the maximum rate of the polymerization of fibrin produced in the fibrinogen + thrombin reaction

\begin{tabular}{l|c}
\hline \multicolumn{1}{c|}{ Compound } & $\mathrm{IC}_{50}, \mathrm{M}$ \\
\hline C-192 & $1.26 \times 10^{-6}$ \\
C-98 & $1.31 \times 10^{-4}$ \\
1. para-hydroxyphenyl- & $>1.0 \times 10^{-4}$ \\
methylene-bis-phosphonic acid & $0.72 \times 10^{-4}$ \\
\hline
\end{tabular}


$\boldsymbol{A}$

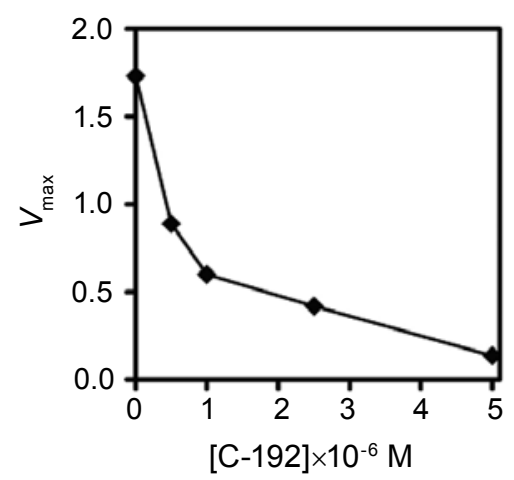

B

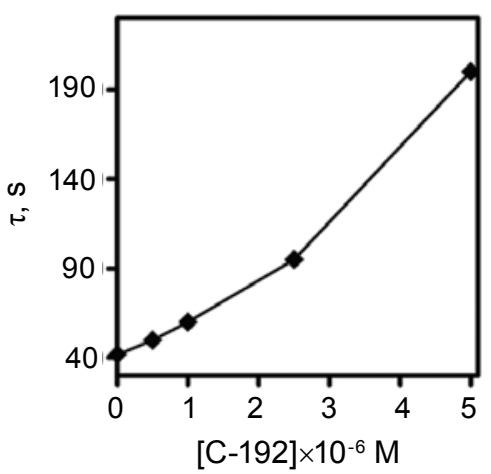

C

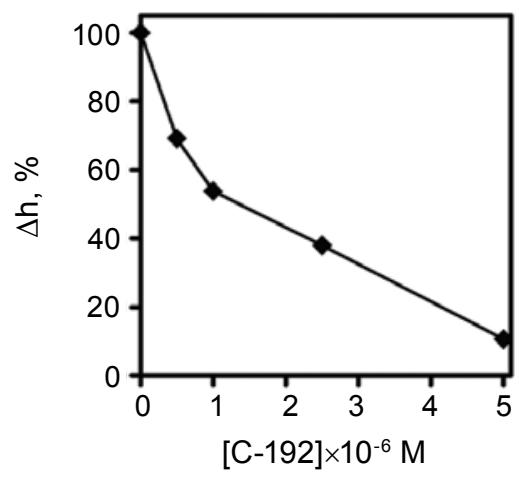

Fig. 11. Turbidity analysis of the influence of C-192 on fibrin polymerization in the fibrinogen + thrombin reaction. The dependence on calixarene $C-192$ concentration is shown for $(A)$ the maximum rate of fibrin polymerization $V_{\max },(\boldsymbol{B})$ the lag-time $\tau$ and $(\boldsymbol{C})$ the final turbidity of fibrin clots $\Delta h$

$\mathrm{IC}_{50}$ value was $>1.0 \cdot 10^{-4} \mathrm{M}$ for 1 and $0.72 \cdot 10^{-4} \mathrm{M}$ for 2 .

It is of interest that the inhibitory activity of C-98, which has the two methylene-bis-phosphonic acid substituents, is much less (Table 2) $\left(\mathrm{IC}_{50}=1.31 \cdot 10^{-4} \mathrm{M}\right)$, indicating that the calixarene scaffold and the number of phosphoryl groups in the molecule play a crucial role in the inhibitory effect.

Furthermore, calixarene C-192 doubles both the prothrombin time (PT) and APTT in normal human blood plasma at concentrations of $7.13 \cdot 10^{-5} \mathrm{M}$ and $1.10 \cdot 10^{-5} \mathrm{M}$, respectively (Fig. 15). The molar ratios of C-192 to plasma fibrinogen were approximately $21: 1$ and $3.3: 1$ for the PT and APTT assays, respectively. The delays in clotting times in the blood plasma coagulation experiments are what would be expected by the inhibition of the fibrin polymerization from fibrinogen after the activation of the blood coagulation sys- tem. Electron microscopy confirmed that C-192 inhibits the first stage of fibrin polymerization (i.e. the formation of protofibrils).

Because this stage is fulfilled through the intermolecular binding of the complementary sites 'A'-'a', it appeared to be certain that this inhibition is a result of the blocking of site 'A' (Aa17-19, GlyProArg) by the calixarene in a 'knob-hole' manner. To confirm that this was the case, we employed HPLC to study complex formation between C-192 and the synthetic peptide Gly-Pro-Arg-Pro, a synthetic analogue of the A knob; the free amino acids Gly, Pro and Arg were used as controls. Association constants of calixarene C-192 complexes with amino acids Gly, Pro, Arg and tetrapeptide Gly-Pro-Arg-Pro in methanol-water mobile phase $(50: 50, \mathrm{v} / \mathrm{v})$ were determined as previously described [17, 18]. The addition of calixarene C-192 to the mobile phase decreased the capacity factor, $k^{\prime}$, of the guest molecules (Table 3 ). This confirms
A

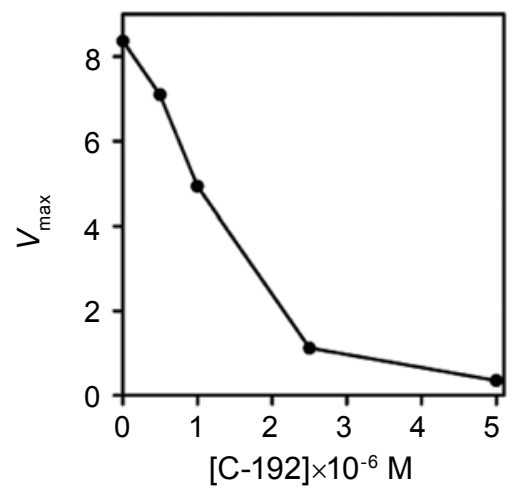

B

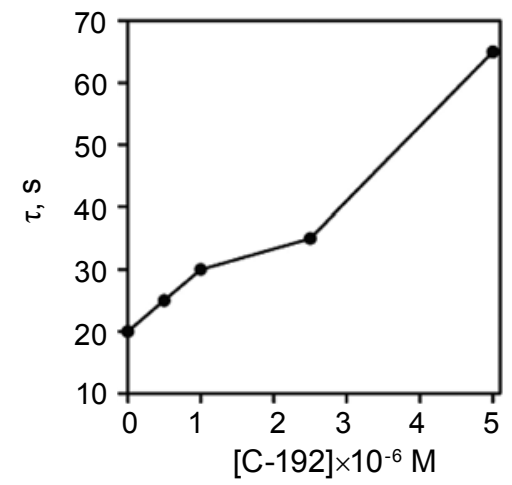

C

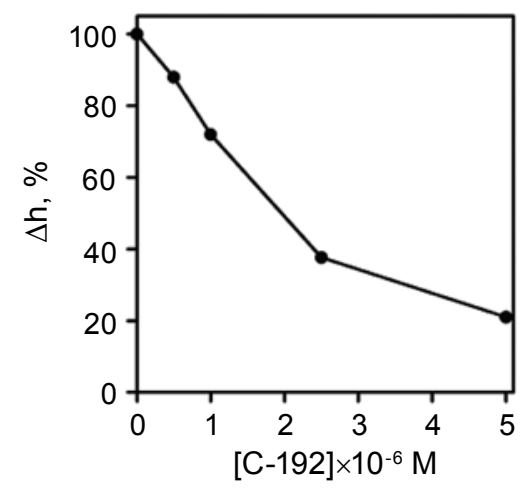

Fig. 12. Turbidity analysis of the influence of $C-192$ on fibrin desAB polymerization. The dependence on calixarene $C-192$ concentration is shown for $(\boldsymbol{A})$ the maximum rate of fibrin polymerization $V_{\max }$, $(\boldsymbol{B})$ the lagtime $\tau$ and $(C)$ the final turbidity of fibrin clots $\Delta h$ 
A

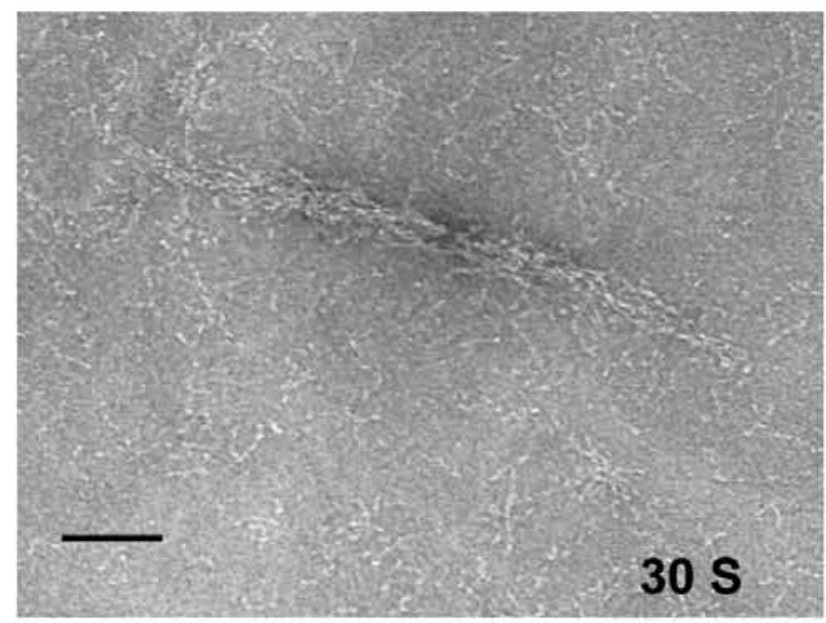

C

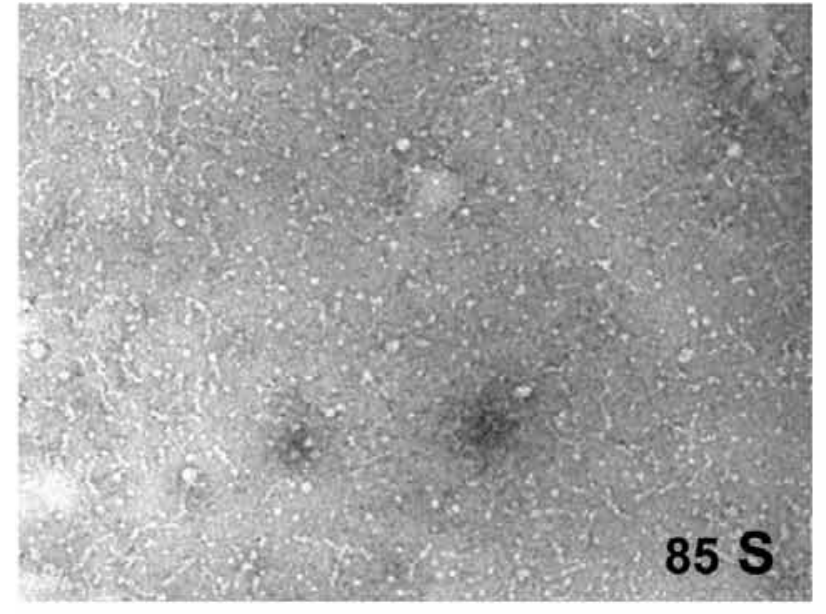

B

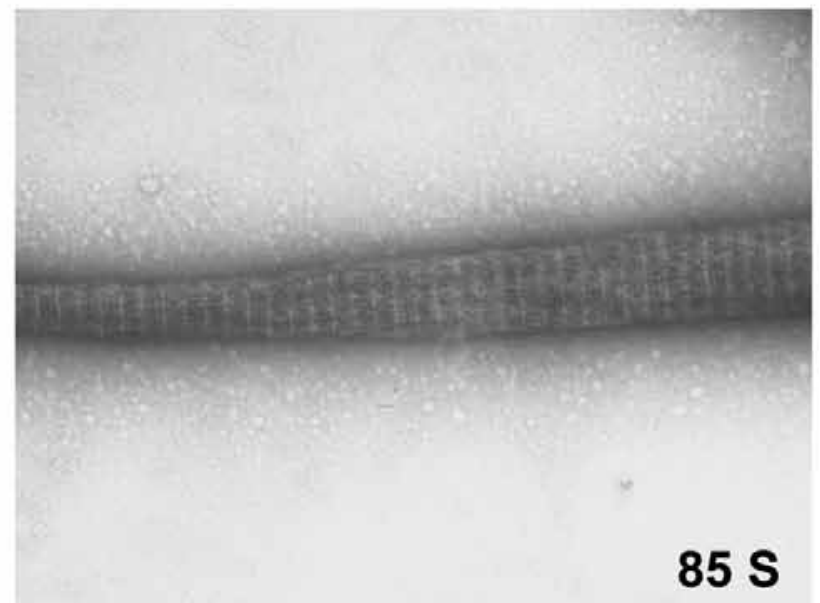

D

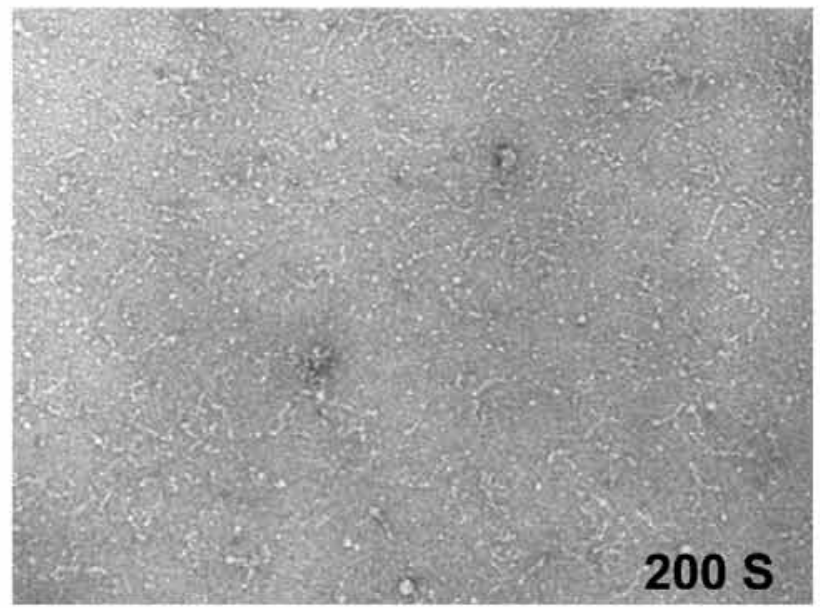

Fig. 13. Electron micrographs of fibrinogen + thrombin reaction media in the absence of $C-192(\boldsymbol{A}, \boldsymbol{B})$, as well as in its presence $(\boldsymbol{C}, \boldsymbol{D})$. Scale bar $=100 \mathrm{~nm}$

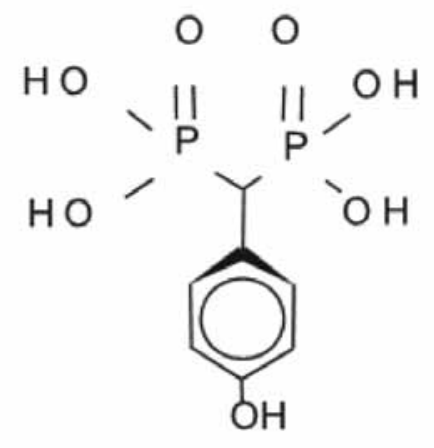

1<smiles>O=P(O)(O)CP(=O)(O)O</smiles>

2

Fig. 14. Two structural fragments of C-192: para-hydroxyphenyl-methylene-bis-phosphonic acid (1) and methylene-bis-phosphonic acid (2) 

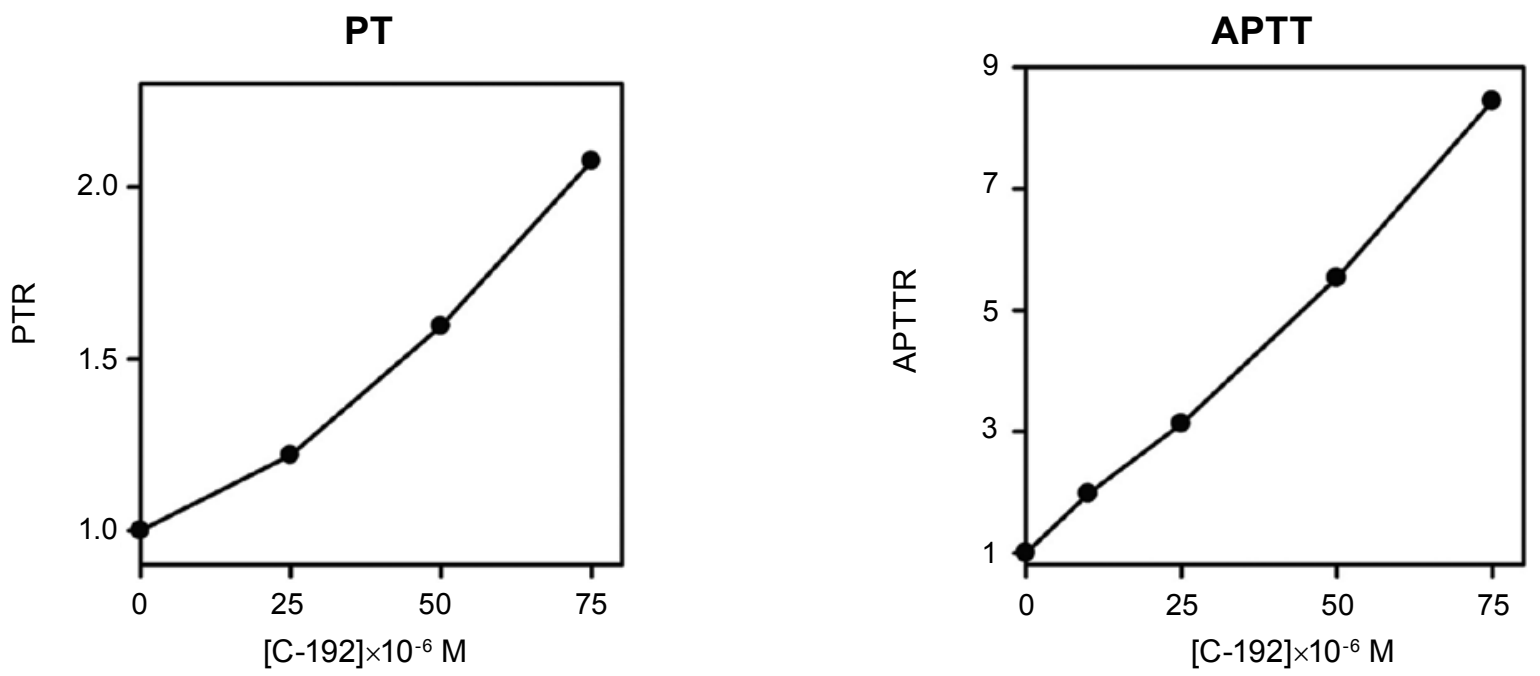

Fig. 15. The dependence of the PT and APTT ratios on the calixarene C-192 concentration

the formation of inclusion host-guest complexes. There is linear dependence of $1 / k^{\prime}$ versus the concentration of C-192 in the mobile phase (Fig. 16); the correlation coefficient is $0.98-0.99$, indicating a 1: 1 ratio of calixarene to Gly-Pro-Arg-Pro in the complex.

In accordance with the molecular modelling data (Fig. 17, $A, B$ ), there are two modes of C-192-Gly-Pro-Arg-Pro complexation. In the first mode (A), cooperative electrostatic interactions of two proximal negatively-charged phosphonyl groups with the Gly $\alpha$-amino terminal group and the Arg guanidinium residue play a principal role in complex formation. Most of the tetrapeptide molecule is exposed outside the calixarene cavity. In the second mode (B), the hydrophobic part of Gly-Pro-Arg-Pro molecule is deeply embedded into the calixarene cavity. The complex is stabilized by $\mathrm{P}_{-} \mathrm{O}^{-} \ldots \mathrm{H}_{3} \mathrm{~N}^{+}$electrostatic interactions of the phosphonyl group with the Gly amino acid residue, as well as by $\mathrm{CH}-\pi$ interactions of $\mathrm{CH}_{2}$-group in the Pro residue with the calixarene aromatic ring. Hydrophobic forces can additionally stabilize the complex in a water solution.

Thus, we have shown for the first time that C-192 is a powerful and specific inhibitor of the final step of blood coagulation, fibrin polymerization, and can be used as the basis for the design of new class of anti-thrombotic agents. We have found that the mechanism of C-192 inhibition involves its effect on the first step of fibrin polymerization, protofibril formation, which is carried out via intermolecular interactions of complementary polymerization sites ' $A$ ' and ' $a$ ' of fibrin molecules.

We have also shown that C-192 forms complex with synthetic peptide Gly-Pro-Arg-Pro, which imitates polymerization site 'A' (Aa17 GlyPro-Arg), suggesting that the inhibitory effect of C-192 may be a result of the blocking of site 'A' by this calixarene.

The previous scientific experiments with healthy adult mice have shown that the calixarene $\mathrm{C}-192$ is median toxic compound $\left(\mathrm{LD}_{50}\right.$ is $780 \mathrm{mg} / \mathrm{kg}$, perorally).

Table 3. Values $1 / k^{\prime}$ of the guests and association constants $K A\left(M^{-1}\right)$ for their complexes with calixarene $C$-192. RSD, relative standard deviation

\begin{tabular}{|c|c|c|c|c|c|c|}
\hline \multirow{3}{*}{ Guest } & \multicolumn{5}{|c|}{ Calixarene concentration } & \multirow{3}{*}{$K_{\mathrm{A}}, \mathrm{M}^{-1}(\mathrm{RSD}, \%)$} \\
\hline & 0.0 & 1.48 & 2.52 & 3.54 & 5.00 & \\
\hline & \multicolumn{5}{|c|}{$1 / k^{\prime}$} & \\
\hline Gly & 0.302 & 0.313 & 0.324 & 0.331 & 0.349 & $280(10)$ \\
\hline Pro & 0.294 & 0.318 & 0.367 & 0.396 & 0.403 & $814(26)$ \\
\hline Arg & 0.311 & 0.395 & 0.532 & 0.592 & 0.794 & $2576(21)$ \\
\hline Gly-Pro-Arg-Pro & 1.287 & 1.754 & 2.453 & 3.015 & 3.693 & 3395 (19) \\
\hline
\end{tabular}




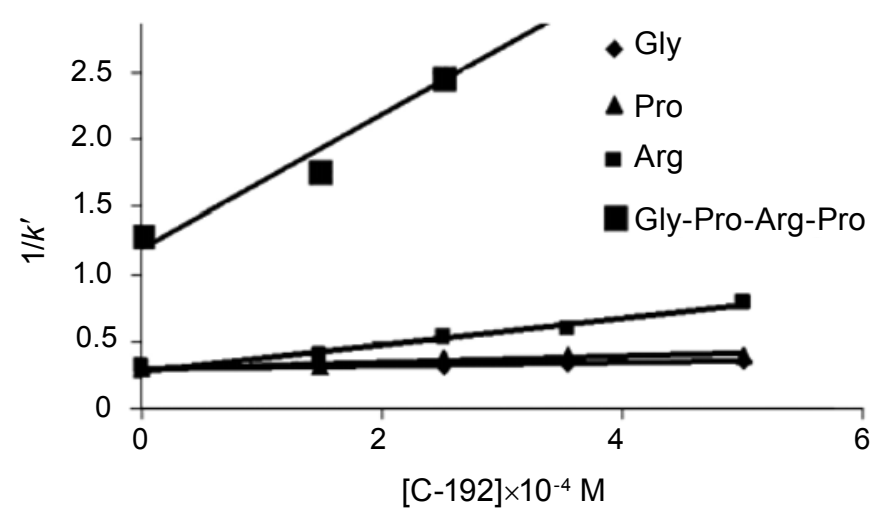

Fig. 16. Dependence of $1 / k^{\prime}$ for Gly, Pro, Arg and Gly-Pro-Arg-Pro on theC-192 concentration in the mobile phase
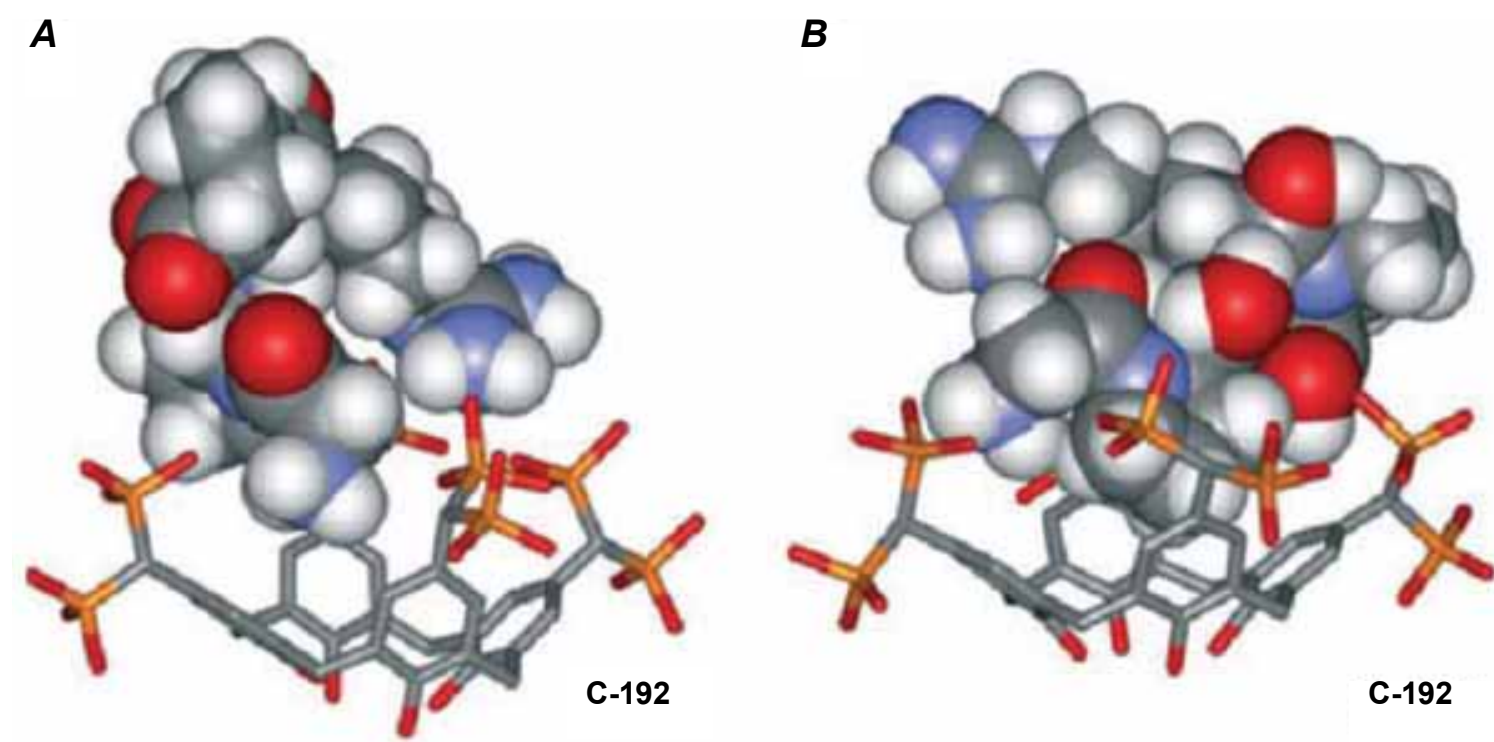

Fig. 17. Two modes of energy minimized structures of calixareneC-192 complexed with GlyProArgPro. (A) Cooperative electrostatic interactions of two proximal negatively charged phosphonyl groups of C-192 molecule with Glya-amino terminal group and Arg guanidinium residue. (B) The hydrophobic part of GlyProArgPro molecule is embedded into the calixarene cavity

These experiments demonstrate that calix[4]arene C-192 (calixarene tetrakis-methylene bisphosphonic acid) is a specific inhibitor of fibrin polymerization and blood coagulation can be used for the design of a new class of antithrombotic agents.

We believe that our data make a contribution to modern knowledge about biochemical and biophysical properties of calixarenes and the molecular mechanism of their interactions with proteins. Taking into account the ability of calixarenes to penetrate into the cell and their low toxicity, these data may be used as a basis for the further development of a new generation of the supramolecular effectors for regulation of smooth muscle contractile activity at the level of ATP dependent actin-myosin interaction and can be used for the design of a new class of antithrombotic agents.

The authors express their gratitude to R. D. Labintseva, O. A. Bevza and O. V. Bevza, T. A. Pozniak (Koshel), P. G. Gritsenko (Palladin Institute of Biochemistry, NAS of Ukraine) and S. O. Tcherenok, S. O. Cherenok (Institute of Organic Chemistry, NAS of Ukraine) for their active participation in experimental investigations as well as O. Yu. Tchunikhin (Palladin Institute of Biochemistry, NAS of Ukraine) for assistance in performing experiments on photon-correlation spectrophotometer 
and Chernishov V. I. for assistance in performing experiments on electron microscopy.

The study was realized due to financial support of the complex targeted interdisciplinary program of NAS of Ukraine for scientific researches "Fundamental grounds of molecular and cellular biotechnologies" project N13/1(4)-31/10 and "Preparation of substance for medical purpose” project $N$ 5.16.4.37$20 / 10$.

\section{КАЛИКСАРЕНМЕТИЛЕНБИС- ФОСФОНОВЫЕ КИСЛОТЫ КАК ПЕРСПЕКТИВНЫЕ ЭФФЕКТОРЫ БИОХИМИЧЕСКИХ ПРОЦЕССОВ}

С. В. Комисаренко ${ }^{l}$, С. А. Костерин ${ }^{l}$, Э. В. Луговской

\author{
${ }^{1}$ Институт биохимии им. А. В. Палладина \\ НАН Украины, Киев; \\ e-mail: kinet@biochem.kiev.ua; \\ ${ }^{2}$ Институт органической химии \\ НАН Украины, Киев; \\ e-mail: vik@ioch.kiev.ua
}

Эта работа - результат междисциплинарного исследования, совместно выполненного сотрудниками Института биохимии им. А. В. Палладина и Института органической химии НАН Украины, и посвященная анализу действия некоторых каликсаренметиленбисфосфоновых кислот (циклических олигомеров фенолов) на два хорошо известных биохимических процесса: $\mathrm{Mg}^{2+}$-зависимый энзиматический гидролиз АТР (катализируемый субфрагментом-1миозина миометрия) и на полимеризацию фибрина.

Молекула каликс[4]арена С-97 представляет собой макроцикличекую структуру, содержащую внутримолекулярную липофильную «чашу», сформированную из четырех ароматических колец, одно из которых по верхнему венцу функционализировано метиленбисфосфоновой группой. Это вещество, используемое в концентрации 100 мкМ, эффективно ингибировало АТРазную активность субфрагмента-1 миозина миометрия (коэффициент ингибирования $I_{05}=83 \pm 7$ мкM). В то же время этот каликс[4]арен вызывал существенное (относительно контрольного значения) увеличение величины гидродинамического диаметра молекулы субфрагмента-1, что опосредовано указывало на образование межмолекулярного комплекса между каликсареном и головкой миозина. Результаты компьютерного моделирования, проведенные с использованием докинга и методов молекулярной динамики, свидетельствуют о том, что в стабилизации указанного межмолекулярного комплекса существенное значение принадлежит гидрофобным, электростатическим и $\pi$ - $\pi$-стэкинг взаимодействиям. Полученные результаты, с учетом низкой токсичности каликсаренов и их способности проникать в клетки, могут быть перспективными для создания высокоэффективных регуляторов (на уровне АТР-зависимого взаимодействия актина и миозина) сократительной активности гладких мышц.

Исследовано влияние на полимеризацию фибрина каликс[4]аренов, содержащих два или четыре метиленбисфосфоновые группы на верхнем венце макроцикла. Наиболее мощным ингибитором оказался каликс[4]арентетрабисметиленбисфосфоновая кислота (С-192). Максимальная скорость полимеризации фибрина в системе фибриноген + тромбин уменьшается на $50 \%$ при концентрации каликсарена $0,52 \cdot 10^{-6} \mathrm{M}\left(\mathrm{IC}_{50}\right)$, при этом молярное соотношение каликсарена и фибриногена равняется $1,7: 1$. При полимеризации фибрина desAB, $\mathrm{IC}_{50}$ составляет $1,26 \cdot 10^{-6} \mathrm{M}$, в тоже время молярное соотношение C-192 и мономерного фибрина составляет $4: 1$. Дипропоксикаликс[4]аренбисметиленбисфосфоновая кислота (С-98) ингибирует полимеризацию фибрина desAB c $\mathrm{IC}_{50}=1,31 \cdot 10^{-4} \mathrm{M}$. Мы предположили, что C-192 блокирует полимеризацию фибрина путем связывания с сайтом полимеризации «А» (Aa17-19), который инициирует формирование протофибрилл за счет «knob-hole» взаимодействий. Это предположение подтверждено с помощью метода ВЭЖХ, показавшего образование комплекса включения по типу «гостьхозяин» C-192 с синтетическим пептидом GlyPro-Arg-Pro, аналогом сайта «A». Дальнейшее подтверждение того, что каликсарен С-192 действует на начальную стадию полимеризации фибрина, получено с помощью электронного микроскопа. Установлено, что в присутствии каликсарена в среде реакции не формируются даже протофибриллы. Каликсарен С-192 вдвое увеличивает протромбиновое время и частично активирует тромбопластиновое время в нормальной плазме крови человека при концентрации $7,13 \cdot 10^{-5}$ и $1,10 \cdot 10^{-5} \mathrm{M}$ соответственно. Эти эксперименты показывают, что C-192 является специфическим ингибитором полимеризации фибрина и свертывания крови и может быть использован для разработки нового класса антитромботических препаратов.

Ключевы е слова: метиленбисфосфоновая кислота, каликсарены, активность АТРазы, докинг, полимеризация фибрина, фибриноген, фибрин, ингибирование. 


\section{КАЛІКСАРЕНМЕТИЛЕНБІС- ФОСФОНОВІ КИСЛОТИ ЯК ПЕРСПЕКТИВНІ ЕФЕКТОРИ БІОХІМІЧНИХ ПРОЦЕСІВ}

\section{C. В. Комісаренко ', С. О. Костерін ${ }^{l}$, \\ Е. В. Луговськой ${ }^{\prime}$ В. І. Кальченко}

'Інститут біохімії ім. О.В.Палладіна

НАН Україны, Київ;

e-mail: kinet@biochem.kiev.ua;

${ }_{2}^{2}$ Інститут органічної хімії НАН України, Київ; e-mail: vik@ioch.kiev.ua

Ця робота - результат міждисциплінарного дослідження, виконаного спільно співробітниками Інституту біохімії ім. О. В. Палладіна та Інституту органічної хімії НАН України і присвячена аналізу дії деяких каліксаренметиленбісфосфонових кислот (циклічних олігомерів фенолів) на два добре відомих біохімічних процеси: $\mathrm{Mg}^{2+}$-залежний ензиматичний гідроліз АТР (що каталізується субфрагментом 1 міозину міометрія) та на полімерізацию фібрину.

Молекула калікс[4]арену C-97 має макроциклічну структуру, містить внутрішньомолекулярну ліпофільну «чашу», яка сформована $з$ чотирьох ароматичних циклів, один $з$ яких на верхньому вінці містить метиленбісфосфонову групу. Зазначений каліксарен, використаний в концентрації 100 мкМ, ефективно інгібує АТРазну активність субфрагмента-1 міозина міометрія (коефіцієнт інгібування $I_{0,5}=83 \pm 7$ мкМ). У той же час цей каліксарен спричинює істотне (щодо контрольного значення) збільшення величини гідродинамічного діаметра молекули субфрагмента-1, що опосередковано вказує на утворення міжмолекулярного комплексу між каліксареном та голівкою міозину. Результати комп'ютерного моделювання, які було проведено із використанням технології докінгу та методів молекулярної динаміки, вказують на те, що у стабілізації зазначеного молекулярного комплексу істотне місце належить гідрофобним, електростатичним та $\pi$ - $\pi$-стекінг взаємодіям. Одержані результати, із урахуванням низької токсичності каліксаренів та їхньої здатності проникати в клітини, можуть бути перспективними для подальшої розбудови високоефективних регуляторів (на рівні АТР-залежної взаємодії актину та міозину) скоротливої активності гладеньких м'язів.

Досліджено вплив на полімеризацію фібрину калікс[4]аренів, які містять два або чотири метиленбісфосфонові групи на верх- ньому вінці макроциклу. Найпотужнішим інгібітором виявився калікс[4]арентетрабісметиленбісфосфонова кислота (С-192). Максимальна швидкість полімеризації фібрину в системі фібриноген+тромбін зменшувалась на $50 \%$ за концентрації каліксарену $0,52 \cdot 10^{-6} \mathrm{M}$ $\left(\mathrm{IC}_{50}\right)$, при цьому молярне співвідношення каліксарену до фібриногену дорівнює $1,7: 1$. У разі полімеризації фібрину desAB, $\mathrm{IC}_{50}$ становить $1,26 \cdot 10^{-6} \mathrm{M}$, у той же час молярне співвідношення С-192 до мономерного фібрину дорівнює $4: 1$. Дипропоксикалікс[4]аренбісметиленбісфосфонова кислота (C-98) інгібувала полімеризацію фібрину desAB $3 \mathrm{IC}_{50}=1,31 \cdot 10^{-4}$ М. Ми припустили, що С-192 блокує полімеризацію фібрину шляхом зв'язування із сайтом полімеризації «A» (Аа17-19), який ініціює формування протофібрил за рахунок «knob-hole» взаємодій. Це припущення підтверджено за допомогою методу BEPX, який показав утворення комплексу включення за типом «гістьгосподар» С-192 із синтетичним пептидом Gly-Pro-Arg-Pro, аналогом сайту «А». Подальше підтвердження того, що каліксарен C-192 діє на початкову стадію полімеризації фібрину одержано за допомогою електронного мікроскопа. Встановлено, що в присутності каліксарену в середовищі реакції не формуються навіть протофібрили. Каліксарен С-192 вдвічі збільшував, як протромбіновий час, так і активований частково тромбопластиновий час у нормальній плазмі крові людини за концентраціі $7,13 \cdot 10^{-5}$ i $1,10 \cdot 10^{-5} \mathrm{M}$ відповідно. Ці експерименти показують, що C-192 є специфічним інгібітором полімеризації фібрину та зсідання крові і може бути використаний для розробки нового класу антитромботичних препаратів.

К л ю ч о в і с л о в а: метиленбісфосфонова кислота, каліксарени, активність АТРази, докінг, полімеризація фібрину, фібриноген, фібрин, інгібування.

1. Gutsche C. D. Calixarenes: an introduction, monographs in supramolecular chemistry. Royal Society of Chemistry. Cambridge, 2008.

2. Calixarenes 2001. Asfari M.-Z., Böhmer V., Harrowfield J., Vicens J. (eds.). - Kluwer Academic Publishers. Dordrecht, 2001.

3. Calixarenes for Separations. Lumetta G. J., Rogers R. D., Gopalan A.S. (eds). - American Chemical Society. Washington, 2000.

4. Calixarenes in the Nanoworld. Vicens J., Harrowfield J. (eds). - Springer. Dordrecht. The Netherlands, 2007. 
5. Da Silva E., Lazar A. N., Coleman A. W. // J. Drug. Sci. Tech. - 2004. - 14. - P. 3-20.

6. Rodik R. V., Boyko V. I., Kalchenko V. I. // Curr. Med. Chem. - 2009. - 16. - P. 16301655.

7. Weinstein R. S., Roberson P. K., Manolagas S. C. // N. Engl. J. Med. - 2009. - 360. - P. 53-62.

8. Gnant M., Mlineritsch B., Schippinger $W$. // N. Engl. J. Med. - 2009. - 360. - P. 679-691.

9. Gulaya N. M., Komisarenko S. V. / Uspekhi biologicheskoy Khimii. - M.: Nauka, 1982. 22. - C. 195-213.

10. Komisarenko S. V., Karlova N. P., Kolesnikova I. N. et al. / Chemistry and biology of immunoregulators: [Collected papers] / Acad. Sci. Latv. SSR, Inst. org. Synthesis; [Editorial board: G. I. Chipens (editor-in-chief) et al.]. Riga: Zinante, 1985. - P. 237-252.

11. Komisarenko S. V., Gulaya N. M., Borisenro A. M., Veller O. S. // Reports Acad. Sci. USSR. - 1979. - P. 563-566.

12. Komisarenko S. V., Kolesnikova I. N., Fomovskaya G. N. // Ukr. Biokhim. Zhurn. - 1985. 57. - P. 62-66.

13. Komisarenko S. V., Fomovskaya G. N., Kolesnikova I. N. et al. // Ukr. Biokhim. Zhurn. 1985. - 57. - P. 56-61.

14. Fomovskaya G. N., Komisarenko S. V. // Biokhimia. - 1985. - 50. - P. 839-843.

15. Gaivoronskaya G. G., Komisarenko S. V. // Ukr. Biokhim. Zhurn. - 1983. - 55. - P. 403-407.

16. Smirnova I. N., Kudryavtseva N. A., Komissarenko $S$. V. et al. // Arch. Biochem. Biophys. 1988. - 267. - P. 280-284.

17. Karlova N. P., Komissarenko S. V. // Reports Acad. Sci. USSR. - 1981. - P. 68-70.

18. Gulaya N. M., Bogomolets E. O., Karlova N. P., Komissarenko S. V. // Farmakologia i toksikologia. - 1980. - XLIII. - P. 192-195.

19. Gaivoronskaya G. G., Strelchuk S. I., Komissarenko $S$. V. // Tsitologia i genetika. 1981. - 15. - P. 41-45.

20. Fomovskaya G. N., Komissarenko S. V. // Chemistry of tumors in USSR. - 1987. Issue 48: Materials of III All-Union meeting «Actual problems of experimental chemotherapy of tumors», Chernogolovka, November, 1987. - P. 14-16.

21. Sharykina N. I., Kudriavtseva I. G., Komissarenko $S$. V., Karlova N. P. // Chemistry of tumors in USSR. - 1987. - Issue 48: Materials of III All-Union meeting «Actual problems of experimental chemotherapy of tumors», Chernogolovka, November, 1987. - P. 12-13.

22. Curry J. D., Nicholson D. A., Quimby O. T. // Top. Phosphorus Chem. - 1972. - 7. - P. 37-102.
23. Vovk A. I., Kalchenko V. I., Cherenok S. O. et al. // Org. Biomol. Chem. - 2004. - 2. P. 3162-3166.

24. Lugovskoy E. V., Gritsenko P. G., Koshel T. A. et al. // FEBS J.-2011. - 278. - P. 1244-1251.

25. Khataee H. R., Khataee A. R. // Digest J. Nanomater. Biostruct. - 2009. - 4. - P. 613621.

26. Burghardt T. P., Neff K. L., Wieben E. D. et al. // BMC Genomics. - 2010. - 11. P. 172. http://www.biomedcentral.com/14712164/11/172.

27. Bárány M., Bárány K. Biochemistry of Smooth Muscle Contraction / Ed. Bárány M. Chicago: Academic Press. - 1996. - 418 p.

28. Kaliman I. A., Grigorenko B. L., Shadrina M. S., Nemukhin A. V. // Phys. Chem. Chem. Phys. 2009. - 11. - P. 4804-4807.

29. Popov E. M., Demin V. V., Shibanova E. D. Problem of protein. - 2: Three-dimensional structure of protein / Edited by T. I. Sorokina. M: Nauka, 1996. - 480 p.

30. Levitsky D. I. // Biokhimia. - 2004. - 69. P. 1447-1462.

31. Bevza A. A., Labintseva R. D. , Rodik R. V. et al. // Ukr. Biokhim. Zhurn. - 2009. - 81. P. 49-58.

32. Bárány M., Bárány K., Gaetijens M., Balin G. // Arch. Biochem. Biophys. - 1966. - 113. P. 205-211.

33. Weber A. // Biochem. Biophys. Acta. - 1956. 19. - P. 345-351.

34. Weeds A. G., Taylor R. S. // Nature. - 1975. 257. - P. 54-56.

35. Bradford M. M. // Anal. Biochem. - 1976. 72. - P. 248-282.

36. Laemmly U. K. // Nature (London). - 1970. 227. - P. 680-685.

37. Iwane A. H., Kitamura K., Tokunaga M. et al. // Biochem. Biophys. Res. Commun. - 1997. 230. - P. 76-80.

38. Chen P. S., Toribara Jr., T. Y., Warner H. // Analyt. Chem. - 1956. - 28. - P. 1756-1758.

39. Kurganov V. I. Allosteric enzymes. - M.: Nauka, 1978. - 248 p.

40. Merkus H. G. Particle Size Measurements. Fundamentals, Practice, Quality. - Springer. 2009. - 533 p.

41. Storn R. M., Price K. // J. Glob. Optim. 1997. - P. 341-359.

42. Case D. A., Pearlman D. A., Caldwell J. W. et al. / AMBER 7. University of California, San Francisco. -2002 . -318 p.

43. Berman H. M., Westbrook J., Feng Z. et al. // Nucl. Acids Res. - 2000. - 28. - P. 235-242.

44. Van Der Spoel D., Lindahl E., Hess B. et al. // J. Comput. Chem. - 2005. - 26. - P. 1701-1719. 
45. Allen M. P., Tildesley D. J. / Computer Simulation of Liquids. Oxford: Clarendon Press. - 2002. - 385 p.

46. Li L., Jose J., Xiang Y., Kuhn R. J., Rossmann M. G. // Nature. - 2010. - 468. P. 645-646.

47. Korostylev P. P. / Preparing solutions for chemico-analytical researches. Publishers Acad. Sci USSR. - 1964. - 310 p.

48. Burgess S. A., Yu S., Walker M. L. et al. // J. Mol. Biol. - 2007. - 372. - P. 1165-1178.

49. Proteins and Cell Regulation. Myosins. A Superfamily of Molecular Motors / Ed. Coluccio L. M. - Watertown, MA, USA.: Springer. - 2008. - 7. -467 p.

50. Baby G. J., Warsaw D. M., Periasamy M. // Microsc. Res. Tech. - 2000. - 50. - P. 532-540.

51. Burgess S. A., Yu S., Walker M. L. et al. // J. Mol. Biol. - 2007. - 372. - P. 1165-1178.

52. Veklich T. O., Kosterin S. A., Rodik R. V. et al. // Ukr. Biokhim. Zhurn. - 2006. - 78. P. 70-78.

53. Cherenok S. O., Yuschenko O. A., Gritsenko P. G. et al. // Phosphorus Sulfur Silicon Relat. Elem. - 2011. - 186. - P. 964-965.
54. Blomback B. // Thromb. Res. - 1996. - 83. P. 1-75.

55. Laudano A. P., Doolittle R. F. // Proc. Natl. Acad. Sci. USA. - 1978. - 75. - P. 3085-3089.

56. Fowler W. E., Hantgan R. R., Hermans J., Erickson H. P. // Proc. Natl. Acad. Sci. USA. 1981. - 78. - P. 4872-4876.

57. Weisel J. W., Veklich Y., Gorkun O. // J. Mol. Biol. - 1993. - 232. - P. 285-297.

58. Weisel J. W. // Biophys. J. -1986. - 50. P. 1079-1093.

59. Spraggon G., Everse S. J., Doolittle R. F. // Nature. - 1997. - 389. - P. 455-462.

60. Varetskaya T. V. // Ukr. Biokhim. Zhurn. 1960. - 32. - P. 13-24.

61. Belitser V. A., Varetskaja T. V., Malneva G. V. // Biochim. Biophys. Acta. - 1968. - 154. P. 376.

62. Lugovskoi E. V., Makogonenko E. M., Chudnovets V. S. et al. // Biomed. Sci. 1991. - 2. - P. 249-296. 